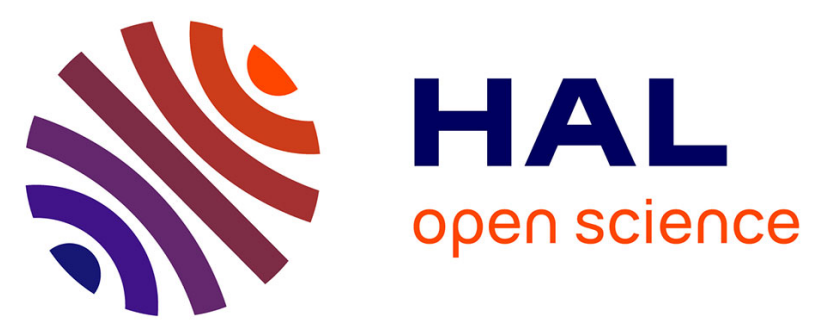

\title{
First reprocessing of Southern Hemisphere ADditional OZonesondes (SHADOZ) profile records (1998-2015): 1. Methodology and evaluation
}

\author{
Jacquelyn Witte, Anne M. Thompson, Herman G. J. Smit, Masatomo \\ Fujiwara, Françoise Posny, Gert J. R. Coetzee, Edward T. Northam, Bryan J. \\ Johnson, Chance W. Sterling, Maznorizan Mohamad, et al.
}

\section{To cite this version:}

Jacquelyn Witte, Anne M. Thompson, Herman G. J. Smit, Masatomo Fujiwara, Françoise Posny, et al. First reprocessing of Southern Hemisphere ADditional OZonesondes (SHADOZ) profile records (1998-2015): 1. Methodology and evaluation. Journal of Geophysical Research: Atmospheres, 2017, 122 (12), pp.6611 - 6636. 10.1002/2016JD026403 . hal-01595774

\section{HAL Id: hal-01595774 \\ https://hal.univ-reunion.fr/hal-01595774}

Submitted on 2 Sep 2021

HAL is a multi-disciplinary open access archive for the deposit and dissemination of scientific research documents, whether they are published or not. The documents may come from teaching and research institutions in France or abroad, or from public or private research centers.
L'archive ouverte pluridisciplinaire HAL, est destinée au dépôt et à la diffusion de documents scientifiques de niveau recherche, publiés ou non, émanant des établissements d'enseignement et de recherche français ou étrangers, des laboratoires publics ou privés.

$$
\text { Copyright }
$$




\section{Journal of Geophysical Research: Atmospheres}

\author{
RESEARCH ARTICLE \\ 10.1002/2016JD026403 \\ Key Points: \\ - This is the first major reprocessing of \\ SHADOZ ozonesonde data records \\ - The effect of reprocessing is observed \\ throughout the profile, and the \\ magnitude of change is highly \\ variable and station dependent \\ - Reductions in satellite biases are due \\ to ozonesonde reprocessing \\ techniques that correct for errors in \\ operating procedures
}

Supporting Information: - Table S1

Correspondence to:

J. C. Witte,

jacquelyn.witte@nasa.gov

\section{Citation:}

Witte, J. C., et al. (2017), First reprocessing of Southern Hemisphere ADditional OZonesondes (SHADOZ) profile records (1998-2015): 1. Methodology and evaluation, J. Geophys. Res. Atmos., 122, 6611-6636, doi:10.1002/2016JD026403.

Received 19 DEC 2016 Accepted 27 APR 2017

Accepted article online 1 MAY 2017

Published online 19 JUN 2017

O2017. American Geophysical Union All Rights Reserved.

\section{First reprocessing of Southern Hemisphere ADditional OZonesondes (SHADOZ) profile records (1998-2015):} 1. Methodology and evaluation

\author{
Jacquelyn C. Witte ${ }^{1,2}$ (D, Anne M. Thompson ${ }^{2}$ (D, Herman G. J. Smit ${ }^{3}$, Masatomo Fujiwara 4 (iD, \\ Françoise Posny $^{5}$ (D), Gert J. R. Coetzee ${ }^{6}$, Edward T. Northam ${ }^{1,7}$ (D), Bryan J. Johnson ${ }^{8}$ (D), \\ Chance W. Sterling ${ }^{8,9}$ iD, Maznorizan Mohamad ${ }^{10}$, Shin-Ya Ogino ${ }^{11}$ (D), Allen Jordan ${ }^{8,9}$, \\ and Francisco R. da Silva ${ }^{12}$
}

\begin{abstract}
${ }^{1}$ Science Systems and Applications Inc., Lanham, Maryland, USA, ${ }^{2}$ NASA/Goddard Space Flight Center, Greenbelt, Maryland, USA, ${ }^{3}$ Institute of Chemistry and Dynamics of the Geosphere: Troposphere, Research Centre Juelich, Juelich, Germany, ${ }^{4}$ Faculty of Environmental Earth Science, Hokkaido University, Sapporo, Japan, ${ }^{5}$ Department of Physics, University of La Réunion Island, Réunion, France, ${ }^{6}$ South African Weather Service, Erasmusrand, Pretoria, South Africa, ${ }^{7}$ NASA/Wallops Flight Facility, Wallops Island, Virginia, USA, ${ }^{8}$ Global Monitoring Division, NOAA, Earth System Research Laboratory, Boulder, Colorado, USA, ${ }^{9}$ Cooperative Institute for Research in Environmental Sciences, University of Colorado Boulder, Boulder, Colorado, USA,

${ }^{10}$ Malaysian Meteorological Department, Ministry of Science, Technology and Innovation, Petaling Jaya, Malaysia, ${ }^{11}$ Department of Coupled Ocean-Atmosphere-Land Processes Research, Japan Agency for Marine-Earth Science and Technology, Yokosuka, Japan, ${ }^{12}$ Brazilian Institute of Space Research, Laboratory of Environmental and Tropical Variables, Natal, Brazil
\end{abstract}

Abstract Electrochemical concentration cell ozonesonde measurements are an important source of highly resolved vertical profiles of ozone $\left(\mathrm{O}_{3}\right)$ with long-term data records for deriving $\mathrm{O}_{3}$ trends, model development, satellite validation, and air quality studies. Ozonesonde stations employ a range of operational and data processing procedures, metadata reporting, and instrument changes that have resulted in inhomogeneities within individual station data records. A major milestone is the first reprocessing of seven Southern Hemisphere ADditional OZonesondes (SHADOZ) station ozonesonde records to account for errors and biases in operating/processing procedures. Ascension Island, Hanoi, Irene, Kuala Lumpur, La Réunion, Natal, and Watukosek station records all show an overall increase in $\mathrm{O}_{3}$ after reprocessing. Watukosek shows the largest increase of $9.0 \pm 2.1$ Dobson Units (DU) in total column $\mathrm{O}_{3}$; Irene and Hanoi show a $5.5 \pm 2.5 \mathrm{DU}$ increase, while remaining sites show statistically insignificant enhancements. Negligible to modest $\mathrm{O}_{3}$ enhancements are observed after reprocessing in the troposphere (up to 8\%) and stratosphere (up to 6\%), except at La Réunion for which the application of background currents reduces tropospheric $\mathrm{O}_{3}(-2.1 \pm 1.3 \mathrm{DU})$. Inhomogeneities due to ozonesonde/solution-type changes at Ascension, Natal, and La Réunion are resolved with the application of transfer functions. Comparisons with EP-TOMS, Aura's Ozone Monitoring Instrument and Microwave Limb Sounder (MLS) satellite $\mathrm{O}_{3}$ overpasses show an overall improvement in agreement after reprocessing. Most reprocessed data sets show a significant reduction in biases with MLS at the ozone maximum region (50-10 hPa). Changes in radiosonde/ozonesonde system and nonstandard solution types can account for remaining discrepancies observed at several sites when compared to satellites.

Plain Language Summary Ozonesondes are point-source balloon-borne instruments that measure profiles of ozone, pressure, temperature, and relative humidity from the surface up to $10 \mathrm{hPa}(\sim 30 \mathrm{~km})$. Long-term ozonesonde data records are relied upon to validate model output and satellite retrievals of ozone, as well as validate their trend calculations. Thus, it is important to have confidence in the quality and accuracy of sonde observations. One way to ensure high quality in the ozonesonde measurement system is to follow the consensus-based operating procedures and reprocessing guidelines established by ozonesonde experts from around the world. These procedures and guidelines have been adopted by the SHADOZ (Southern Hemisphere ADditional OZonesondes) network. SHADOZ is a NASA/GSFC project in close collaboration with NOAA and other international partners to archive tropical and sub-tropical ozonesonde data. Since the network started in 1998, 14 stations located north and south of the tropics have archived over 6000 profiles. Like many long-term observational networks, SHADOZ is characterized by heterogeneous operating procedures, ozonesonde systems, and postprocessing software that impact validation and trend derivation assessments. Reprocessing the SHADOZ ozonesonde data records has led to homogenized data sets that now allow for meaningful comparisons across the network. 


\section{Introduction}

Electrochemical concentration cell (ECC) ozonesondes are balloon-borne instruments that use an electrochemical technique [Vetter, 1967] to make in situ measurements of ozone from the surface to an altitude determined by balloon burst, typically 30 to $35 \mathrm{~km}$. The sonde is interfaced to a meteorological radiosonde for transmission of the ozone current and PTU (pressure, temperature, and relative humidity) data to the ground. Studies by Smit et al. [2007] and Thompson et al. [2007] find $\pm 10 \%$ for a $1 \sigma$ uncertainty in the overall profile measurements (reported in World Meteorological Organization [WMO], 2011).

Ozonesonde measurements fulfil an important role in the air quality, climate, model, and satellite communities by providing vertically well-resolved ozone $\left(\mathrm{O}_{3}\right)$ profiles from the surface to the lower and middle stratosphere, capable of collecting data during periods of no sunlight, cloudy conditions, and can be easily deployed from remote locations. Because long-term satellite-based measurements of $\mathrm{O}_{3}$ in the troposphere and upper troposphere/lower stratosphere (UT/LS) are not currently available, the ozonesonde record provides the primary source for deriving $\mathrm{O}_{3}$ trends in the free troposphere and in the climate sensitive region around the tropopause where there are strong $\mathrm{O}_{3}$ vertical gradients.

SHADOZ (Southern Hemisphere ADditional OZonesondes), a NASA-sponsored project that augments and archives ECC ozonesonde data from over a dozen tropical stations, is the premier network for vertical profiles of $\mathrm{O}_{3}$ in the tropics/subtropics and remote regions. Started in 1998 with NOAA and international coinvestigators from Asia, Africa, South America, and Europe, SHADOZ has become an important resource that complements model and satellite validation studies and contributes to climatologies and trend analyses in tropical $\mathrm{O}_{3}$. SHADOZ ozonesonde data are publicly available online at $<$ https://tropo.gsfc.nasa.gov/shadoz $>$.

Like many long-term sounding stations, ozone profile data in the SHADOZ network have been characterized by variations in technique and instrumentation. Thus, there are variations in satellite $\mathrm{O}_{3}$ biases versus sondes, biases among stations, and discontinuities within the data record of an individual station that contribute to measurement uncertainties that may limit the reliability of $\mathrm{O}_{3}$ profile trends [Thompson et al., 2007, 2012, 2014].

To address inhomogeneities in ozonesonde data records, the World Calibration Center for Ozonesondes at the Forchungszentrum, Jülich, Germany periodically conducts intercomparison experiments (JOSIE, Jülich Ozone Sonde Intercomparison Experiment) under controlled laboratory conditions to establish quality assessment standards for ozonesonde sensors [Smit and Kley, 1998; Smit and Straeter, 2004a, 2004b]. JOSIE1996 results show that differences among ECC sensors at that time were largely due to differences in the preparation and correction procedures applied by the different sites [Smit and Kley, 1998]. This was confirmed in the JOSIE-2000 assessment of the performance of various combinations of ECC sensor and solution types [Smit and Straeter, 2004b]. The BESOS (Balloon Experiment on Standards for Ozonesondes) follow-on campaign to JOSIE-2000 tested these same combinations in the field [Deshler et al., 2008]. BESOS was able to characterize the response of commonly used ECC manufacturer/solution pairings following JOSIE guidelines on standard operating procedures (SOP). A compact linear relationship between standard ECC pairs was found, allowing the possibility of deriving transfer functions to homogenize data sets that use different ECC sensors and solution strengths within their records. Deshler et al. [2017] provide detailed documentation on the derivation of the transfer functions that WMO/GAW recommends for various ozonesonde types and solutions. The World Meteorological Organization/Global Atmosphere Watch Report \#201 [Smit et al., 2014] (hereafter referred to as WMO/GAW) is based on the JOSIE and BESOS results and provides guidance and recommendations on SOP. The ASOPOS (Assessment for Standards on Operating Procedures for Ozone Sondes) review [Smit et al., 2012] (hereafter referred to as ASOPOS) provides reprocessing techniques and transfer functions between sensor and solution types to generate homogenized data sets and uncertainty estimates for $\mathrm{O}_{3}$. SOP and reprocessing procedures summarized in WMO/GAW and ASOPOS have been designed to reduce random errors by maintaining consistent and reproducible ozonesonde measurements. Uniformity in SOP have been shown to decrease the uncertainty in individual soundings to within $\pm 10 \%(1 \sigma)$, while nonuniformity in SOP leads to inhomogeneities in station time series and among station data records [Smit et al., 2007, Deshler et al., 2008]. Smit et al. [2012, 2014] demonstrate that standardization and homogenization of ozonesonde data records improve the precision and accuracy by about a factor of 2. Tarasick et al. [2016] have 


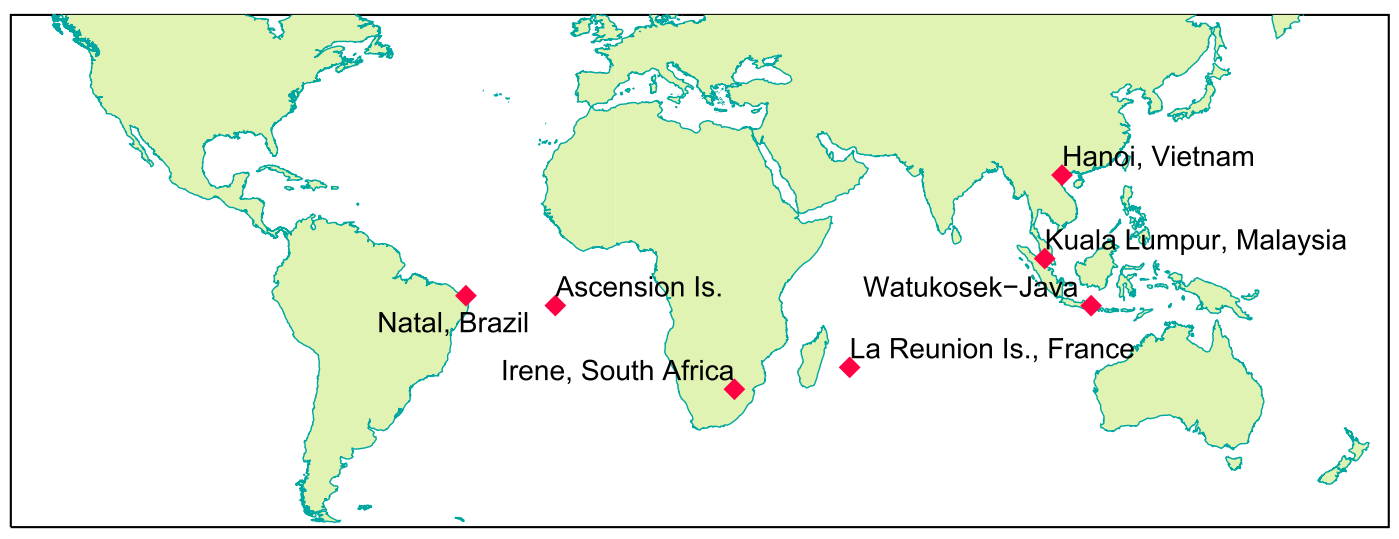

Figure 1. Map of SHADOZ sites for which data sets have been reprocessed.

reprocessed the Canadian ozonesonde network records using some of the principles set forth by ASOPOS guidelines.

Following reprocessing recommendations and guidelines by ASOPOS several SHADOZ station principal investigators have participated in the reprocessing of their data for the first time. We present reprocessed data results for the following stations: Ascension Island (United Kingdom), Hanoi (Vietnam), Irene (South Africa), Kuala Lumpur (Malaysia), La Réunion (France), Natal (Brazil), and Watukosek (Java, Indonesia) mapped in Figure 1. These stations launched 2 to 4 times per month. Table 1 shows variations in local launch times and time period of each reprocessed. This study uses the 1998-2015 records. Irene resumed twice monthly launches in the latter half of 2012. Watukosek has temporarily halted operations since late 2013. Hanoi is the latest station to join SHADOZ in September 2004.

This paper begins with an overview of the ozonesonde measurement system (section 2) followed by a brief description of the ozonesonde instrumentation and sensing solution types in section 3 . The reprocessing approach and methodology based on the ASOPOS guidelines are described in section 4 and form the backbone of this study. Section 5 presents the analyses that compare the original and reprocessed time series at each station and makes further comparisons with satellite observations in section 6 to examine biases and remaining inhomogeneities, if any, in the reprocessed data records. The summary appears in section 7.

Table 1. SHADOZ Stations for Which Data Records Have Been Reprocessed

\begin{tabular}{|c|c|c|c|c|c|}
\hline Station Name & Location & $\begin{array}{l}\text { Local Launch } \\
\text { Times }\end{array}$ & $\begin{array}{l}\text { Reprocessing } \\
\text { Time Period }\end{array}$ & Profile \# & $\begin{array}{l}\text { ECC Sensor/Solution } \\
\text { Pairings Used }\end{array}$ \\
\hline Ascension Island, UK & $7.98^{\circ} \mathrm{S}, 14.42^{\circ} \mathrm{W}$ & $1300-1400$ & $1998-08 / 2010$ & 552 & $\begin{array}{c}\text { SPC/1.0\% } \\
\text { ENSCI/1.0\% (92 records 1998-2001) }\end{array}$ \\
\hline Natal, Brazil & $5.42^{\circ} \mathrm{S}, 35.38^{\circ} \mathrm{E}$ & $1200-1400$ & $\begin{array}{l}1998-2015 \text { (05/2011 } \\
-09 / 2013 \text { data gap) }\end{array}$ & 548 & $\begin{array}{c}\text { SPC/1.0\% } \\
\text { ENSCI/1.0\% (104 records 1998-2002) }\end{array}$ \\
\hline Irene, South Africa & $25.90^{\circ} \mathrm{S}, 28.22^{\circ} \mathrm{E}$ & $1000-1300$ & $\begin{array}{c}\text { 07/1998-11/2015 } \\
\text { (2008-08/2012 data gap) }\end{array}$ & 306 & $\mathrm{SPC} / 1.0 \%$ \\
\hline Watukosek, Indonesia & $7.57^{\circ} \mathrm{S}, 112.65^{\circ} \mathrm{E}$ & $1200-1300$ & $06 / 2001-10 / 2013$ & 243 & ENSCI/2.0\% unbuffered \\
\hline Kuala Lumpur, Malaysia & $2.73^{\circ} \mathrm{N}, 101.70^{\circ} \mathrm{E}$ & $1000-1200$ & 1998-2015 & 363 & $\begin{array}{c}\text { SPC/1.0\% (1998-11/2014) } \\
\text { ENSCI/0.5\% (12/2014 - present) } \\
\text { Unknown (44 records 03/2010-2011) }\end{array}$ \\
\hline La Réunion, France & $21.10^{\circ} \mathrm{S}, 55.48^{\circ} \mathrm{E}$ & 0800-1500 & 1998-2015 & 570 & $\begin{array}{c}\text { ENSCI/1.0\% (first } 8 \text { records in 1998) } \\
\text { SPC/0.5\% (40 records 1999-2000) } \\
\text { ENSCI/0.5\% half and full buffer } \\
19 \text { records in } 2006 \text { with an unknown } \\
\text { buffer for ENSCI/ } 0.5 \%\end{array}$ \\
\hline Hanoi, Vietnam & $21.10^{\circ} \mathrm{S}, 105.80^{\circ} \mathrm{E}$ & $1300-1400$ & $\begin{array}{l}\text { 09/2004-2015 (very few } \\
\text { soundings in 2010-2012) }\end{array}$ & 220 & $\begin{array}{c}\text { ENSCI/2.0\% unbuffered } \\
\text { (2004-01/2010; launches in 01/2011, } \\
\text { 01/2013, and 08/2015) } \\
\text { SPC/1.0\% (15 records in } 2009 \text { and } 2010) \\
\text { ENSCI/0.5\% (07/2010 up to present) }\end{array}$ \\
\hline
\end{tabular}




\section{The Ozonesonde Measurement}

The electrochemical concentration cell (ECC) ozonesonde sensor developed by Komhyr [1969] consists of a nonreactive Teflon gas-sampling piston pump connected to an electrochemical sensor containing a buffered potassium iodide $(\mathrm{KI})$ solution in the cathode cell and a saturated $\mathrm{KI}$ solution in the anode cell. The ECC sensor measures ozone using iodine/iodide electrode reactions [Vetter, 1967]. Both cells contain a phosphate buffer to maintain a neutral $\mathrm{pH}$. An ion bridge connecting the two chambers allows electrons to flow between the two cells but prevents mixing, thereby preserving their respective concentrations. An interface board connects the ozone sensor to a radiosonde for data telemetry of the main parameters: the cell current, the sonde's pump temperature, pump motor voltage and current, and ambient temperature, pressure, and relative humidity (RH) [Komhyr et al., 1995]. In flight, the instrument is encased in a polystyrene weatherproof box that is tethered to a balloon. The data transmission rate is typically $1 \mathrm{~Hz}$. The balloon ascent rate of around $5 \mathrm{~m} \mathrm{~s}^{-1}$ and a 20-30 second range of ECC response times result in a vertical resolution of about 100$150 \mathrm{~m}$ [Komhyr, 1969].

The relationship between the ozone measurement and the electrical current (in units of microampere, $\mu \mathrm{A}$ ) is determined by the following equation that originates from Komhyr [1969]:

$$
P_{\mathrm{O}_{3}}=4.307 \times 10^{-4} \frac{\left(I_{M}-I_{B}\right) T_{P} \Phi \Psi}{\eta}
$$

where $P_{\mathrm{O} 3}=$ ozone partial pressure, $\mathrm{mPa} ; I_{M}=$ cell current, $\mu \mathrm{A} ; I_{B}=$ cell background current, $\mu \mathrm{A}$; $T_{P}=$ ozonesonde pump temperature, $\mathrm{K} ; \Phi=$ pump flow rate, $\mathrm{s} / 100 \mathrm{~mL} ; \psi=$ pump flow efficiency $=1 /$ pump flow correction factor, unitless; and $\eta=$ conversion efficiency which is generally assumed to be 1 .

The constant, $4.307 \times 10^{-4}$, is the half ratio of the ideal gas constant to Faraday's constant. The cell current, $I_{M}$, and pump temperature, $T_{p}$, are in situ measurements while the cell background current, $I_{B}$, and flow rate, $\Phi$, are constant values measured during preflight preparations under ambient conditions for each instrument. The pump flow efficiency, $\psi$, is taken from a table of calibrated measurements at low pressures to account for the decrease in pump efficiency. The $\psi$ values vary with ECC instrument type and are addressed in greater detail in section 4.4. The conversion efficiency, $\eta$, includes the stoichiometric factor of $1: 1$ assumed in the $\mathrm{I}_{2}: \mathrm{O}_{3}$ relationship and the ozone absorption efficiency from the gas to liquid phase.

\section{ECC Instruments and Solution Pairings}

All SHADOZ stations use one or a combination of two ECC sensor manufacturers: Science Pump Corporation (SPC) and Environmental Science (EN-SCI) Corporation. The manufacturers of EN-SCI ECC sensors are EN-SCI before 2011, Droplet Measurement Technologies (DMT) Inc. during 2011-2015, and a new EN-SCI Corporation after 2015. The first operating guidelines for preparing ozonesondes for flight were created for the SPC 4A model in the NOAA technical memorandum [Komhyr, 1986]. The current manual has been optimized for the SPC 6A model design [Science Pump Corporation, 1999] flown during the SHADOZ time period. The original EN-SCI Corporation started in the early 1990s with a similar ECC sensor instrument configuration to that of the SPC 5A model. EN-SCI Corporation [1996] is the first operations handbook for the $1 \mathrm{Z}$ and $2 \mathrm{Z}$ models. The most recent EN-SCI manual has been published by Droplet Measurement Technologies [2014]. The $1 \mathrm{Z}$ model fits older generation Vaisala radiosondes, and the $2 \mathrm{Z}$ model comes with a V2C type interface board that connects to the InterMet and Graw DFM-97 radiosondes. Other radiosondes with TMAX or proprietary interface boards, such as Modem or Vaisala RS92, use the Z model. One difference between the V2C and TMAX boards is the data transfer rate: $1.2 \mathrm{~s}$ for the former, and 7 to $8 \mathrm{~s}$ for the latter.

A variety of sensing solution concentrations and $\mathrm{pH}$ buffers have been used in combination with the two different ECC sonde types. Table 2 summarizes the $\mathrm{KI}$ sensing solution formulas most commonly used in the ECC cathode cells and in the SHADOZ network. The anode solutions are prepared by saturating the cathode solution with excess $\mathrm{KI}$ crystals. The $1.0 \%$ and $0.5 \%$ solutions (Table 2 , bold) are the standard concentrations recommended by ASOPOS for the SPC and EN-SCI sondes, respectively, and are used in six of the sites shown in Table 1 for which we reprocessed data. Watukosek used the $2.0 \%$ non-pH-buffered, or unbuffered, solution in its entire data record (2001-2013). This solution formula was introduced by Birdsall et al. [1952] and adopted at all NOAA-affiliated stations in the SHADOZ network: Samoa, Fiji, and Hilo-Hawaii. By mid-2000 these stations switched solutions to a $1.0 \% \mathrm{Kl}, 1 / 10 \mathrm{pH}$-buffer formula. The Hanoi station is unique 
Table 2. Cathode Sensing Solutions ${ }^{a}$

\begin{tabular}{|c|c|c|c|c|}
\hline \multirow[b]{2}{*}{ Sensing Solution Type } & \multicolumn{4}{|c|}{ pH Buffer ${ }^{b}$} \\
\hline & $\mathrm{KI}$ & $\mathrm{NaH}_{2} \mathrm{PO}_{4} \cdot \mathrm{H}_{2} \mathrm{O}$ & $\mathrm{Na}_{2} \mathrm{HPO}_{4} \cdot 12 \mathrm{H}_{2} \mathrm{O}$ & $\mathrm{KBr}$ \\
\hline $1.0 \% \mathrm{KI}$, full buffer & 10 & 1.25 & 5.0 & 25 \\
\hline $0.5 \% \mathrm{KI}$, half buffer & 5 & 0.625 & 2.5 & 12.5 \\
\hline $2.0 \% \mathrm{KI}$, no buffer ${ }^{\mathrm{C}}$ & 20 & 0 & 0 & 0 \\
\hline $1.0 \% \mathrm{KL}, 1 / 10$ buffer $^{\mathrm{C}}$ & 10 & 0.125 & 0.5 & 25 \\
\hline $0.5 \% \mathrm{Kl}$, full buffer ${ }^{\mathrm{d}}$ & 5 & 1.25 & 5.0 & 12.5 \\
\hline
\end{tabular}

in that it is dominated by the $2.0 \%$ unbuffered solution in the first half of the data records and the standard $0.5 \%$ solution in the latter half. La Réunion is the only station to use the $0.5 \%$ full buffer, instead of the standard half buffer, since August 2007. Solution type has remained unchanged at the Irene and Watukosek stations over their entire record.

\subsection{Transfer Functions}

Since the mid-1980s, intercomparison campaigns and laboratory studies have been conducted to evaluate the ECC sonde performance using different sensing solution recipes with the two sensor types [Hilsenrath et al., 1986; Boyd et al., 1998; Johnson et al., 2002; Smit and Straeter, 2004b; Smit et al., 2007; Deshler et al., 2008]. The JOSIE studies have shown that the precision and accuracy are strongly dependent on the pairing of the ozonesonde type and solution [Smit et al., 2007]. In particular, the JOSIE-2000 experiment focused on combinations of ECC and sensing solution types to determine the optimal pairing when compared with a standard UV photometer [Proffitt and McLaughlin, 1983]. Results show a reduction in biases for SPC 6A sondes paired with a 1.0\%, full buffer sensing solution (hereafter referred to as SPC1.0) and for EN$\mathrm{SCI} Z$ sondes that use a $0.5 \%$, half buffer solution (hereafter referred to as ENSCI0.5). Results from the BESOS field campaign showed the best agreement with the inflight $\mathrm{O}_{3}$ photometer for sonde that used SPC1.0 and ENSCI0.5. Given the same solution recipe, EN-SCI measures slightly higher $\mathrm{O}_{3}$ than SPC [Smit et al., 2007]. The difference between SPC1.0 and ENSCI0.5 is within 1.0\% [Smit et al., 2014]. The last column in Table 1 includes a summary of the ECC/solution pairings and time period of use at SHADOZ sites for which data were reprocessed. Transfer functions derived from Deshler et al. [2017] are used in this study. Using Table 1 as a guide, we convert Ascension and Natal partial pressure ozone that have used the $\mathrm{ENSCI} / 1 \%$ full buffer pair (ENSCI1.0) to the SPC1.0 standard using the following relationship:

$$
\begin{aligned}
\mathrm{O}_{3}{ }^{\mathrm{SPC} / 1.0}=R \times \mathrm{O}_{3}{ }^{\mathrm{ENSCl} / 1.0 \quad \text { where } R}=0.96 \text { for } P \geq 30 \mathrm{hPa} \\
R=0.764+0.133 \log _{10}(P) \text { for } P<30 \mathrm{hPa}
\end{aligned}
$$

where $P$ is pressure. Transfer functions have also been applied to La Réunion ozone profiles to convert the nonstandard ENSCI1.0 and SPC/0.5\% half-buffer pairs to the standard ENSCI0.5 using the following equations:

$$
\begin{aligned}
\mathrm{O}_{3}{ }^{\mathrm{ENSCl} / 0.5}=R \times \mathrm{O}_{3}{ }^{\mathrm{ENSCl} / 1.0} \text { where } R & =0.96 \text { for } P \geq 30 \mathrm{hPa} \\
R & =0.90+0.041 \log _{10}(P) \text { for } P<30 \mathrm{hPa}
\end{aligned}
$$

and

$$
\begin{aligned}
\mathrm{O}_{3}{ }^{\mathrm{ENSCl} / 0.5}=\mathrm{O}_{3}{ }^{\mathrm{SPC} / 0.5} / R \quad \text { where } \quad & R=0.96 \text { for } P \geq 30 \mathrm{hPa} \\
R & =0.764+0.133 \log _{10}(P) \text { for } P<30 \mathrm{hPa}
\end{aligned}
$$

Refer to Deshler et al. [2017] for a detailed description of the transfer function formulations.

There is no transfer function for the $\mathrm{EN}-\mathrm{SCl} / 0.5 \%$ full buffered solution pairing. As of this writing, transfer functions are being developed for this unique solution based on laboratory and campaign studies (F. Posny and B. Johnson, personal communication, 2017). Johnson et al. [2002] show that the ozonesonde response is more sensitive to changes in the buffer concentrations than the $\mathrm{KI}$ concentrations. Thus, it is expected that the $0.5 \%$ full buffer solution used at La Réunion will respond similar to that of a $1 \%$ full buffer. 
a

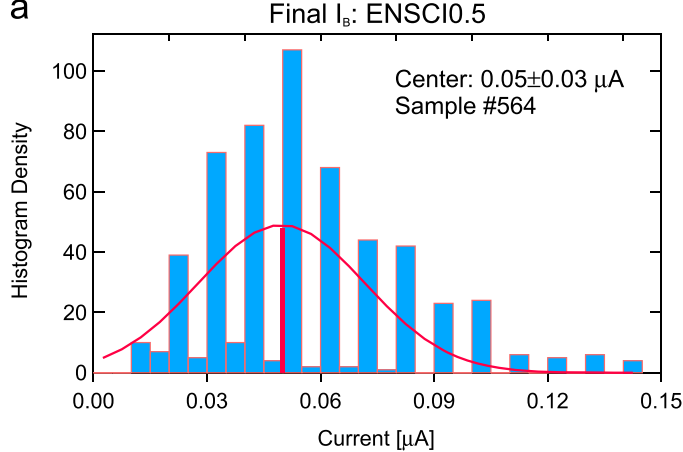

b

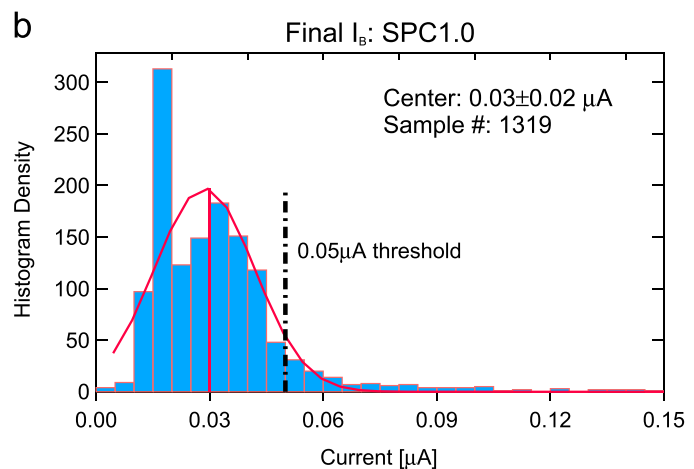

Figure 2. Histogram of the distribution of background currents, $I_{B}$, of the two standard ECC/solution pairings: (a) ENSCI0.5 and (b) SPC1.0. Figure 2a includes $I_{B}$ from La Réunion, Hanoi, and Kuala Lumpur metadata, and Figure $2 b$ includes Irene, Nairobi, Natal, and Ascension metadata. The $0.05 \mu \mathrm{A}$ threshold is marked as the dashed line in Figure $2 \mathrm{~b}$. Red curves are the Gaussian fit to the histograms, and the red vertical line marks the centerfit of the distribution. Bin width is $0.005 \mu \mathrm{A}$.

$\mathrm{NOAA} / \mathrm{GMD}$ has derived a transfer function for $\mathrm{O}_{3}$ profiles that use the $\mathrm{ENSCI} / 2.0 \%$ unbuffered solution (ENSCI2.0) based on the JOSIE-2000 experiment and recommends an additional $2 \%$ be added to the $\mathrm{O}_{3}$ profiles at Watukosek and Hanoi (C. Sterling et al., manuscript in preparation). This $2 \%$ adjustment is a conservative estimate and may be revised.

\section{Reprocessing Approach for SHADOZ Station Data}

Before a launch each ECC sensor is conditioned at least twice, following a repeatable set of operating procedures that is taken either from the manufacturer, the WMO/GAW recommended SOPs, or station-derived procedures. Because each ozonesonde is a unique instrument and responds to conditioning procedures slightly differently, the singular characteristics of each sensor must be recorded. Results are documented in a Check List and stored for traceability and future reprocessing. In particular, the background current and flow rate metadata are parameters in equation (1) so it is critical that these values be documented and archived in perpetuity. The following subsections review the ASOPOS recommended reprocessing procedures for key parameters in the ozone partial pressure equation (1) in order: background current $\left(I_{B}\right)$, absorption efficiency $\left(\alpha_{\mathrm{O} 3}\right)$ which is a component of the conversion efficiency $(\eta)$, pump temperature $\left(T_{P}\right)$, and pump flow rate $(\Phi)$. Although not part of the ECC reprocessing guidelines, the issue of radiosonde pressure sensor offsets [Stauffer et al., 2014] is also included in this section.

\subsection{Background Current Threshold}

The background current $\left(I_{B}\right)$ is the residual current measured by the sonde when sampling ozone-free air. As seen in equation (1), conventional processing of the ozonesonde data subtracts the background current from the measured sensor current $\left(I_{M}-I_{B}\right)$ to calculate the ozone partial pressure. The first set of conditioning procedures is usually carried out several days before the day of flight (DOF) to reduce the background current and stabilize the sensor response time (i.e., the 1/e-folding time for sensor to respond to a step change in ozone) [Komhyr, 1986, 1997]. Komhyr and Harris [1971] show that the background current decreases after the ECC is stored for several days while charged with solutions; they refer to this process as "self-cleaning." Launches made after the first conditioning vary from a day to a few days, a common practice during field campaigns, to weeks under typical SHADOZ station operating conditions. In the latter case, the conditioning may be performed one or more times prior to day of launch with the changing of solutions, a process known as "recharging."

WMO/GAW recommends using the background current recorded immediately prior to launch with the ozonesonde intake tube fitted to an ozone destruction filter. Smit et al. [2012] estimates that properly measured $I_{B}$ since the mid-1990s should be less than $0.05 \mu \mathrm{A}$, given gradual improvements in ECC sensor technology. However, most SHADOZ stations are located in humid tropical environments, which affect the ozone removal efficiency of the destruct filters [Reid et al., 1996; Vömel and Diaz, 2010; Newton et al., 2016]. This can be seen in Figure 2a, for example, where high $I_{B}(>0.05 \mu \mathrm{A})$ for the ENSCI0.5 pairing used at 
Hanoi, La Réunion, and Kuala Lumpur is illustrated. The centerfit (defined here as that $I_{B}$ value of the Gaussian fit to the distribution) is at the Smit et al. [2012] threshold and almost half the $I_{B}$ values exceed $0.05 \mu \mathrm{A}$ with a large tail of the distribution exceeding the $+0.03 \mu \mathrm{A} 1 \sigma$ standard deviation. It appears that the no-ozone filters at these stations were not working optimally. In contrast, $I_{B}$ for the SPC1.0 pairing used at Irene, Natal, Ascension, and Nairobi (another SHADOZ site) shows that $85 \%$ of $I_{B}$ are less than $0.05 \mu \mathrm{A}$; the latter value also marks the $+1 \sigma$ standard deviation from the $0.03 \mu \mathrm{A}$ centerfit. Based on Smit et al. [2012] and the predominance of lower value $I_{B}$ in Figure $2 \mathrm{~b}$, a $0.05 \mu \mathrm{A}$ background threshold is adopted for the six SHADOZ sites that use the standard ENSCI0.5 and SPC1.0 pairs. This means that for records with $I_{B}$ exceeding $0.05 \mu \mathrm{A}, I_{B}$ is set to $0.05 \mu \mathrm{A}$. For Watukosek and Hanoi, cases that use the NOAA sensing solution formula ( $2 \%$ unbuffered), the NOAA/GMD guideline of a $0.04 \mu \mathrm{A}$ threshold is followed (C. Sterling et al., manuscript in preparation).

\subsection{Absorption Efficiency Correction}

The conversion efficiency, $\eta$, is composed of the ozone absorption efficiency, $\alpha_{\mathrm{O} 3}$, from the gas into liquid phase of the sensing solution and the stoichiometry of the chemical conversion of $\mathrm{O}_{3}$ to $I_{2}$ (primarily assumed to be unity). The ozone absorption efficiency is taken as unity where the volume of the cathode solution is $3.0 \mathrm{~cm}^{3}$, i.e., constant absorption efficiency throughout the entire profile. Sites that use the alternate $2.5 \mathrm{~cm}^{3}$ solution volume must be corrected for the reduction in liquid uptake of gaseous ozone in the lower troposphere [Davies et al., 2003]. The following equation is the ASOPOS correction to calculate $\alpha_{\mathrm{O} 3}$ for a $2.5 \mathrm{~cm}^{3}$ volume:

$$
\alpha_{\mathrm{O} 3}(P)=1.0044-4.4 \times 10^{-} 5 \times P \quad \text { for } 100 \mathrm{hPa}<P<1050 \mathrm{hPa}
$$

This is applied to $\eta=\alpha_{\mathrm{O} 3}(P)$ in equation (1).

\subsection{Pump Temperature Correction}

The temperature of the ozonesonde pump, $T_{p}$, accounts for the temperature of the air flowing through the pump. Over time, the location of the ECC thermistor has changed, introducing inhomogeneities in the sounding record [Smit et al., 2014]. In the case of SHADOZ sites, all ECC instruments use an internal pump temperature sensor that is mounted inside the pump body, close to the piston. Internal pump temperatures are considered to be the best approximation to the "true" $T_{P}$ (ASOPOS). Further laboratory experiments that compare piston temperatures to internal pump temperatures found a 1-3 K difference, prompting the following adjustment equation that corrects for this temperature bias (ASOPOS):

$$
T_{P}^{\text {true }}=T_{P}^{\text {measured }}+3.9-0.8 \log _{10}(P)
$$

This correction is applied to all data from the seven SHADOZ sites.

\subsection{Pump Flow Rate Correction}

The pump flow rate, $\Phi$, is a measure of the volume of air displaced $100 \mathrm{~mL}$ through the Teflon pump at ground level. This is a constant value in the ozone calculation regardless of changing ambient conditions or altitude. A common procedure in the ECC conditioning is to use the soap bubble flow meter method to measure the volumetric flow rate of the pump (in units, $\mathrm{s} / 100 \mathrm{~mL}$ ). The required equipment and setup are described in the EN-SCl and SPC manuals (DMT manual, Appendix D, 2014; SPC manual, section 3.2.1, 1999). Several flow rates are measured and the mean, $\Phi$, is applied in equation (1). The uncertainty of the flow rate is generally within $\pm 1 \%$ (ASOPOS).

The flow rate correction takes into account an offset due to evaporation of the sensing solution or the soap bubble solution and is dependent on the laboratory conditions at the time of the flow rate test. Thus, the drier the air when performing the flow rate test, the higher the correction term. At $100 \% \mathrm{RH}$ the correction term would be unity (no evaporation means no offset). The formulae to correct for evaporative effects are found in section 3.2.4 of Smit et al. [2014]. Laboratory PTU during the time of the flow rate test are variables needed to determine this correction. However, these measurements were not recorded in many SHADOZ station Check Lists (refer to each station's documented pump flow rate in Table 4). In this case, we apply an estimated flow rate correction suitable for the tropics assuming $T_{\text {lab }}=25 \pm 5^{\circ} \mathrm{C}$, $\mathrm{RH}_{\mathrm{lab}}=50 \pm 25 \%$, and $P_{\mathrm{lab}}=$ mean pressure surface, $P_{\mathrm{sfc}}$, at launch. For example, for $P_{\mathrm{lab}}=1000 \mathrm{hPa}$ 
Table 3. Radiosonde Type Used by the Reprocessed SHADOZ Sites ${ }^{\mathrm{a}}$

\begin{tabular}{|c|c|c|c|c|}
\hline Site & $\begin{array}{c}\text { Radiosonde Type, } \\
\text { Model }\end{array}$ & Time Period & GPS Availability & $\begin{array}{l}\text { Pressure Offset } \\
\text { Correction }\end{array}$ \\
\hline Ascension & VIZ/Sippican ${ }^{\text {b }}$ & Entire record & Not available & No \\
\hline \multirow[t]{2}{*}{ Natal } & LMS $^{\mathrm{C}}-$ M2LORAN-C & $1998-06 / 2000$ & Not available & No \\
\hline & LMS - Sip GPS LOS-T & $07 / 2000$ up to present & Geopotential heights derived from GPS & N/A \\
\hline \multirow[t]{2}{*}{ Irene } & Vaisala - RS80 & $1998-2008$ & Not available & No \\
\hline & Vaisala - RS92 & $09 / 2012$ up to present & GPS available & Yes \\
\hline Watukosek & Vaisala - RS80 & Entire record & Not available & No \\
\hline \multirow[t]{4}{*}{ Kuala Lumpur } & Vaisala - RS80 & $1998-09 / 2007$ & Not available & No \\
\hline & Vaisala - RS92 & $10 / 2007-02 / 201002 / 2012-11 / 2014$ & GPS available & Yes \\
\hline & Modem - M2 K2 & 03/2010-2011 & Geopotential heights derived from GPS & $\mathrm{N} / \mathrm{A}$ \\
\hline & Changfeng & $12 / 2014$ up to present & Geopotential heights derived from GPS & $\mathrm{N} / \mathrm{A}$ \\
\hline \multirow[t]{3}{*}{ La Réunion } & Vaisala - RS80 & $1998-2006$ & Not available & No \\
\hline & Modem - M2 K2 & $2007-02 / 2013$ & Geopotential heights derived from GPS & $\mathrm{N} / \mathrm{A}$ \\
\hline & Modem - M10 & $03 / 2013$ up to present & Geopotential heights derived from GPS & $\mathrm{N} / \mathrm{A}$ \\
\hline \multirow[t]{4}{*}{ Hanoi } & Vaisala - RS80 & $2004-2006$ & Not available & No \\
\hline & Vaisala - RS92 & $2007-03 / 2014$ & Not available & No \\
\hline & & $04 / 2014$ up to present & GPS available due to software upgrade & Yes \\
\hline & Meisei - RS-06G & 13 soundings in $01 / 2012,01 / 2013$, and $08 / 2015$ & Not available & No \\
\hline
\end{tabular}

\footnotetext{
${ }^{\mathrm{a}} \mathrm{N} / \mathrm{A}$ indicates there are no pressure offsets due to heights derived from GPS measurements.

${ }^{\mathrm{b}}$ Now owned by.

cLockheed Martin Sippican.
}

the flow rate correction is $1.6 \%$. If the \pm 1 sigma values are applied to $T_{\text {lab }}$ and $\mathrm{RH}_{\text {lab }}$, the range of flow rate corrections is $1.1-1.8 \%$.

It has been well documented that the efficiency of the ECC pump decreases at high altitudes [Komhyr, 1967, 1969, 1986; Komhyr et al., 1995; Torres, 1981; Johnson et al., 2002; Smit et al., 2014]. Komhyr et al. [1995] cite pump leakage, dead volume in the piston pump, backpressure exerted on the pump by the cell solution, and solution evaporation as main causes of pump efficiency loss at low pressures. The more recent Johnson et al. [2002] study showed that backpressure is not a significant contributor to the pump efficiency loss, and there is evidence that slow side reactions in buffered solutions will compensate for ozone loss due to evaporation [Saltzman and Gilbert, 1959; Johnson et al., 2002]. Empirical averages obtained from various lab techniques have yielded pump correction factors (PCFs) to apply from $100 \mathrm{hPa}$ to the top of the atmosphere [Komhyr, 1986; Komhyr et al., 1995; Johnson et al., 2002]. Currently, the two most widely used PCFs are taken from Komhyr [1986] and Komhyr et al. [1995] (values are found in Table 3-3 of WMO/GAW). This study uses the WMO/GAW recommendations of Komhyr [1986] and Komhyr et al. [1995] PCFs for the standard ENSCI0.5 and SPC1.0 pairs, respectively. Johnson et al. [2002] PCFs are applied to the ENSCI2.0 records used at Watukosek and Hanoi. The JOSIE-2000 campaign found total column $\mathrm{O}_{3}$ comparisons of ENSCI2.0 sonde records with the reference UV photometer and Dobson spectrophotometer to be within $\pm 5 \%$ when using the Johnson et al. [2002] PCF [Smit et al., 2004b].

\subsection{Radiosonde Pressure Sensor Offsets}

Ozonesondes are interfaced with a radiosonde and typically use their ground station software to calculate ozone. Geopotential heights calculated from radiosonde pressures and temperatures during the pre-GPS (Global Positioning System) radiosonde era led to errors in the height assignment of the computed ozone due to inaccuracies in the pressure sensor [Steinbrecht et al., 2008; Stauffer et al., 2014; Inai et al., 2015]. In particular, height registry errors are prominent at low pressures, above $20 \mathrm{hPa}$, where altitudes derived from GPS compared to those calculated by the radiosonde typically differ by more than $1 \mathrm{~km}$ [Stauffer et al., 2014]. With the addition of GPS receivers to the radiosonde system the accuracy of geometric heights derived from the GPS measurements improved to within $\pm 10 \mathrm{~m}(1 \sigma)$ [Nash et al., 2005]. Whereas there are only two ECC instrument manufacturers, there are a variety of radiosonde manufacturers whose instruments have changed in model, material, and algorithm since the 1970s. Table 3 shows that six radiosonde manufacturers have been used in the seven-station record being reprocessed here. Studies by Steinbrecht et al. [2008], Inai et al. [2009], and Stauffer et al. [2014] note measurable pressure differences between Vaisala RS80 and RS92 models. Radiosonde intercomparison studies by Nash et al. 
[2005, 2011] have been carried out to evaluate performance differences between manufacturers. GPS radiosondes were added to the SHADOZ network gradually after 2000, providing improved altitude measurements and generally eliminating the need for a pressure sensor in the radiosonde measurement system [Nash et al., 2011]. Table 3 summarizes radiosondes used at each SHADOZ site, when GPS radiosondes were introduced, and whether pressure bias corrections have been or can be applied. Modem radiosondes used at La Réunion and briefly at Kuala Lumpur and Changfeng radiosondes calculate pressure and geopotential heights using the GPS receivers [Nash et al., 2011]. Vaisala RS80 radiosondes used in the SHADOZ network do not contain GPS receivers to correct for the height registry offsets. RS80s were used in the entire data record at Watukosek, almost two thirds of the data records at Irene and Kuala Lumpur, half the records at La Réunion, and almost 30\% of those at Hanoi. At present, there is no consensus on how to estimate altitude offsets in the RS80s. In the case of Vaisala RS92s, in which Vaisala introduced GPS receivers, pressure offsets can be determined by calculating the difference between the radiosonde pressures and those derived from the GPS. The RS92 radiosonde performs very well compared to its RS80 predecessor and other competitors [Nash et al., 2011]. Steinbrecht et al. [2008] show excellent precision in RS92s produced after 2004, reporting PTU and GPS heights to be within $25 \mathrm{~m}$ throughout the profile at the Hohenpeissenberg and Lindenberg, Germany, stations. Stauffer et al. [2014] calculate a small RS92 pressure bias of $0.12 \mathrm{hPa}$ overall under ambient conditions. The RS92 is currently flown at Irene, comprises half the data records at Hanoi, and was used briefly at Kuala Lumpur. Unfortunately, RS92 GPS data are missing from the original Hanoi data files from 2007 to March 2014 because an older system and software compatible with the non-GPS RS80 model was used. Thus, no pressure corrections have been applied to these records. Pressure corrections became possible when Hanoi upgraded their Vaisala system to version MW41 after March 2014. Ascension and Natal are postprocessed using software developed by NASA/WFF (Wallops Flight Facility) (F. Schmidlin, personal communication, 2017) that takes into account biases in the launch detection algorithm of the instrument ground station. During the non-GPS era, Ascension (entire record) and Natal (July 1996 - June 2000) profiles were only corrected for the time of launch to correspond to the stations' reference height. The algorithm has been adapted to recalculate geopotential heights at Natal when Sippican Inc. and Lockheed Martin Sippican (LMS) GPS radiosondes were introduced. Note that Ascension discontinued launches in 2010; operations resumed in early 2016 with an EN-SCI/InterMet radiosonde system.

\section{Application of Reprocessing to SHADOZ Sites: Comparison of Original and Reprocessed Data}

Across the SHADOZ network there is a diversity of operating procedures, instrument types, and sensing solutions, with data reporting and formats dependent on the processing software. Thus, a customized approach to reprocessing is required at each site. For each site we do the following:

1. Document each ozonesonde profile metadata from available Check List sheets, metadata archived in the original data files, and historic knowledge of the operating procedures and processing software from the station Principal Investigators and/or operators.

2. Assess the extent to which data can be fully reprocessed. In cases where metadata and Check Lists are missing or incomplete, average values are used for parameters such as background current or pump flow rates.

3. Provide a summary, itemizing what corrections can be applied per profile.

We use the Skysonde postprocessing software developed by Allen Jordan (NOAA/Earth System Research Laboratory/Global Monitoring Division) to evaluate the quality of each profile and apply most of the corrections detailed in section 4. Table 4 is a general summary of each site's metadata and applied corrections based on the ASOPOS reprocessing guidelines explained in the previous section.

Ascension and Natal applied a water vapor dependent correction to the pump flow rate using the Bandy and Torres [1982] formulation. These correction factors are similar to those derived from the WMO/GAW guidelines [Smit et al., 2014, section 3.2.4].

Noteworthy in Table 4 is the treatment of the missing pump temperature profile data in the original Kuala Lumpur and Irene records during the 1998-2005 and 1998-2006 periods, respectively; these coincide with the use of the older generation Vaisala DigiCora ${ }^{\circledR}$ (MARWIN ${ }^{\circledR}$ ) MW15 software processing system used with RS80 model radiosondes. In the current study, monthly mean Vaisala RS80 pump temperature profiles 
Table 4. Summary of Reprocessing Procedures Applied Per Site

Correction Parameter Original Metadata

Time Period

Correction Applied

\begin{tabular}{|c|c|c|c|}
\hline \multicolumn{4}{|c|}{ Ascension Is., U.K.: $1998-08 / 2010$} \\
\hline $\mathrm{ECC} /$ solution & $\begin{array}{l}\mathrm{SPC} / 1.0 \\
\mathrm{ENSCl} / 1.0\end{array}$ & $\begin{array}{l}\text { Entire record } \\
92 \text { records }\end{array}$ & $\begin{array}{l}\text { No } \\
\text { Equation (2) }\end{array}$ \\
\hline Solution volume & $2.5 \mathrm{~cm}^{3}$ & $1998-07 / 1999$ & Equation (5) \\
\hline & $3.0 \mathrm{~cm}^{3}$ & 08/1999 - end & No \\
\hline Background current & $I_{B}$ before launch used & Entire record & $0.05 \mu \mathrm{A}$ threshold \\
\hline Pump flow rate & $\begin{array}{l}\text { Correction using Bandy } \\
\text { and Torres [1982]. }\end{array}$ & Entire record & $\begin{array}{c}\text { Values similar to Smit et al. } \\
\text { [2014] equations }\end{array}$ \\
\hline Pump temperature & Internal pump temperature & Entire record & Equation (6) \\
\hline \multicolumn{4}{|c|}{ Natal, Brazil: 1998-2015 (05/2011-09/2013 Data Gap) } \\
\hline ECC/solution & $\begin{array}{l}\mathrm{SPC} / 1.0 \\
\mathrm{ENSCl} / 1.0\end{array}$ & $\begin{array}{l}\text { Entire record } \\
104 \text { records }\end{array}$ & $\begin{array}{c}\text { No } \\
\text { Equation (2) }\end{array}$ \\
\hline Solution volume & $\begin{array}{l}2.5 \mathrm{~cm}^{3} \\
3.0 \mathrm{~cm}^{3}\end{array}$ & $\begin{array}{l}1998-04 / 1999 \\
05 / 1999-\text { end }\end{array}$ & $\begin{array}{l}\text { Equation (5) } \\
\text { No }\end{array}$ \\
\hline Background current & $I_{B}$ before launch used & Entire record & $0.05 \mu \mathrm{A}$ threshold \\
\hline Pump flow rate & $\begin{array}{l}\text { Correction using Bandy } \\
\text { and Torres [1982]. }\end{array}$ & Entire record & $\begin{array}{c}\text { Values similar to Smit et al. } \\
\text { [2014] equations }\end{array}$ \\
\hline Pump temperature & Internal pump temperature & Entire record & Equation (6) \\
\hline \multicolumn{4}{|c|}{ Irene, South Africa: 07/1998-11/2015 (2008-08/2012 Data Gap) } \\
\hline $\mathrm{ECC} /$ solution & $\mathrm{SPC} / 1.0 \%$ & Entire record & No \\
\hline Solution volume & $2.5 \mathrm{~cm}^{3}$ & Entire record & Equation (5) \\
\hline Background current & $I_{B}$ before launch used & Entire record & $0.05 \mu \mathrm{A}$ threshold \\
\hline Pump flow rate & Lab PTU not available & $1998-06 / 2015$ & $\begin{array}{l}\text { Flow rate correction }=1.9 \% \text { for } T_{\text {lab }} \\
=25^{\circ} \mathrm{C}, \mathrm{RH}_{\mathrm{Lab}}=50 \%, P_{\mathrm{Lab}}=850 \mathrm{hPa}\end{array}$ \\
\hline \multirow{3}{*}{ Pump temperature } & Lab PTU available & 06/2015 - end & Smit et al. [2014] equations \\
\hline & Missing internal pump temperature data & $1998-06 / 2006$ & $\begin{array}{c}\text { Monthly profile climatologies } \\
\text { and apply Equation (6) }\end{array}$ \\
\hline & Internal pump temperature & 07/2006 - end & Equation (6) \\
\hline \multicolumn{4}{|c|}{ Watukosek, Indonesia: 06/2001-10/2013 } \\
\hline $\mathrm{ECC} /$ solution & ENSCI/2.0\% unbuffered & Entire record & Add $+2 \%$ to entire profile \\
\hline Solution volume & $3.0 \mathrm{~cm}^{3}$ & Entire record & No \\
\hline Background current & $I_{B}$ before launch used & Entire record & $0.04 \mu \mathrm{A}$ threshold \\
\hline Pump flow rate & Lab PTU available & Entire record & Smit et al. [2014] equations \\
\hline Pump temperature & Internal pump temperature & Entire record & Equation (6) \\
\hline \multicolumn{4}{|c|}{ Kuala Lumpur, Malaysia: 1998-2015 } \\
\hline \multirow[t]{3}{*}{$\mathrm{ECC} /$ solution } & $\mathrm{SPC} / 1.0 \%$ & $1998-10 / 2014$ & No \\
\hline & Unknown & 03/2010-2011 & No \\
\hline & ENSCI/ $0.5 \%$ & $12 / 2014$ - end & No \\
\hline Solution volume & $3.0 \mathrm{~cm}^{3}$ & Entire record & No \\
\hline Background current & $I_{B}$ before launch used & Entire record & $0.05 \mu \mathrm{A}$ threshold \\
\hline Pump flow rate & Lab PTU not available & $2003-2014$ & $\begin{array}{l}\text { Flow rate correction }=1.6 \% \text { for } T_{\text {lab }} \\
=25^{\circ} \mathrm{C}, \mathrm{RH}\end{array}$ \\
\hline \multirow{3}{*}{ Pump temperature } & Lab PTU available & 2015 & Smit et al. [2014] equations \\
\hline & Missing internal pump temperature data & $1998-03 / 2005$ & $\begin{array}{c}\text { Monthly profile climatologies } \\
\text { and apply Equation (6)) }\end{array}$ \\
\hline & Internal pump temperature & 04/2005 - end & Equation (6) \\
\hline \multicolumn{4}{|c|}{ La Réunion, France: 1998-2015 } \\
\hline \multirow[t]{5}{*}{$\mathrm{ECC} /$ solution } & $\mathrm{ENSCI} / 1.0 \%$ & 8 records & Equation (3) \\
\hline & SPC/ $0.5 \%$ & 40 records & Equation (4) \\
\hline & ENSCI/ $0.5 \%$, half buffer & $1998-05 / 2007$ & No \\
\hline & ENSCI/0.5\%, unknown buffer & 19 records last half of 2006 & No \\
\hline & ENSCI $/ 0.5 \%$, full buffer & 08/2007-2015 & Not available \\
\hline Solution volume & $2.5 \mathrm{~cm}^{3}$ & Entire record & Equation (5) \\
\hline Background current & $I_{B}$ recorded but not applied & Entire record & Add $I_{B}$ and apply $0.05 \mu \mathrm{A}$ threshold \\
\hline Pump flow rate & Lab PTU available & Entire record & Smit et al. [2014] equations \\
\hline Pump temperature & Internal pump temperature & Entire record & Equation (6) \\
\hline \multicolumn{4}{|c|}{ Hanoi, Vietnam: 09/2004-2015 (Data Gaps in 2010-2012) } \\
\hline ECC/solution & $\begin{array}{c}\text { ENSCI/2.0\% unbuffered } \\
\text { SPC/1.0\% }\end{array}$ & $\begin{array}{c}\text { 2004-01/2010, } 17 \text { records } 2011-2015 \\
15 \text { records }\end{array}$ & $\begin{array}{c}\text { Add }+2 \% \text { to entire profile } \\
\text { No }\end{array}$ \\
\hline
\end{tabular}


Table 4. (continued)

\begin{tabular}{|c|c|c|c|}
\hline Correction Parameter & Original Metadata & Time Period & Correction Applied \\
\hline & $\mathrm{ENSCl} / 0.5 \%$ & 07/2010-2015 & No \\
\hline Solution volume & $3.0 \mathrm{~cm}^{3}$ & Entire record & No \\
\hline Background current & $I_{B}$ before launch used & Entire record & $\begin{array}{l}0.04 \mu \mathrm{A} \text { threshold for } 2 \% \text { unbuffered } \\
\text { solution and } 0.05 \mu \mathrm{A} \text { threshold elsewhere }\end{array}$ \\
\hline Pump flow rate & $\begin{array}{l}\text { Lab PTU available } \\
\text { Lab PTU not available }\end{array}$ & $\begin{array}{l}55 \% \text { of record } \\
2011-2015\end{array}$ & $\begin{array}{l}\text { Smit et al. [2014] equations } \\
\text { Flow rate correction }=0.9 \%{ }^{\mathrm{a}} \text { for } T_{\text {lab }} \\
=25^{\circ} \mathrm{C}, \mathrm{RH}\end{array}$ \\
\hline Pump temperature & Internal pump temperature & Entire record & Equation (6) \\
\hline
\end{tabular}

${ }^{a}$ Value based on average lab PTU, where available.

derived from Hanoi, Hilo, Irene, Nairobi, and Samoa SHADOZ profiles (Figure A1) are used to reconstruct the $\mathrm{O}_{3}$ profiles and apply the corrections summarized in Table 4.

For a brief period Kuala Lumpur used the Modem/ozonesonde system between March 2010 and 2011 (refer to Table 3). Unfortunately, the metadata are not available for these data records. In particular, the sensor/solution pairing is unknown so no transfer functions can be assumed. Roughly $69 \%$ of the profiles that used the Modem/ozonesonde system have been omitted from this study because the reprocessed $\mathrm{O}_{3}$ seems erroneously high, generating total column $\mathrm{O}_{3}$ (TCO) values greater than $310 \mathrm{DU}$. Brewer measurements taken close to the Kuala Lumpur site show a 240-285 DU range of TCO values during the 1996-2016 measurement period (M. Mohamad, personal communication, 2017). The reduction in Kuala Lumpur profiles is accounted for in total sample size reported in Table 1 (363 reprocessed profiles compared to 409 profiles present in the original data records).

La Réunion operations do not apply a background current although these values are recorded in the Check Lists. Following ASOPOS reprocessing guidelines we apply the final background current, i.e., measured prior to launch, and use the $0.05 \mu \mathrm{A}$ threshold criteria. During the transition in solution from a $0.5 \%$ half buffer to a full buffer there is a brief period in the latter half of 2006 where the buffering is unknown.

The impact of reprocessing is illustrated in Figure 3 as histograms of integrated column amounts of $\mathrm{O}_{3}$ that display the difference between reprocessed and original profiles. The overall magnitude, distribution, and direction, i.e., increasing or decreasing $\mathrm{O}_{3}$, of each site's data record after reprocessing are observed in the sondes total integrated column $\mathrm{O}_{3}$ amounts ( $\left(\mathrm{CO}^{\text {total }}\right)$. Similarly, the reprocessing impacts in tropospheric and stratospheric ozone columns are examined to indicate where in the column reprocessing has had a significant effect. The ozonopause formulation is used for the tropopause height. This is the height above which the ozone partial pressure increases rapidly [Ivanova, 1974]. This definition has been applied to the SHADOZ data in Thompson et al. [2001, 2007, 2012, 2014], among other studies. Stratospheric columns $\mathrm{O}_{3}$ amounts are calculated by subtracting the tropospheric column $\mathrm{O}_{3}$ from ICO ${ }^{\text {total }}$. Note that the statistics given in Figure 3 are not based on all profiles in the station record summed in Table 1; profiles with significant data gaps or balloon bursts below $15 \mathrm{hPa}$ have been omitted. This pressure cut off is above the $\mathrm{O}_{3}$ peak that is typically around $20 \mathrm{hPa}$ in the tropics.

Histograms at Ascension and Natal (Figures 3a and 3b) exhibit a bimodal distribution due to applying the transfer functions to convert profiles from an ENSCI1.0 pairing to the standard SPC1.0. All distributions at both sites are sharply peaked around their centerfits (center value of the Gaussian fit to the reprocessed-original sonde distributions) with a broad and small secondary negative peak between -5 DU and -10 DU in $\mathrm{ICO}^{\text {total }}$ (Figures $3 \mathrm{a}$ and $3 \mathrm{~b}$, left). The negative peaks are due to the application of transfer functions with most of that decrease occurring in the stratosphere ( $>85 \%$ ) (Figures $3 \mathrm{a}$ and 3b, right). The distribution becomes Gaussian with a much smaller $1 \sigma$ standard deviation if transfer functions are not applied (not shown). Reprocessed Ascension and Natal data show an overall modest increase of 1-5 DU in ICO ${ }^{\text {total }}$ over the original data, with most of the impact again occurring in the stratosphere (centerfit $\sim 3 \mathrm{DU}$ ). The distributions show that tropospheric $\mathrm{O}_{3}$ increases at both stations are small, generally less 1 DU (Figures $3 \mathrm{a}$ and 3b, middle). The SPC1.0 pair dominates the time series at both sites which use the VIZ, Sippican, and now LMS/ozonesonde system and is postprocessed using the NASA/WFF software. Thus, it is not surprising that their responses to reprocessing are similar. 


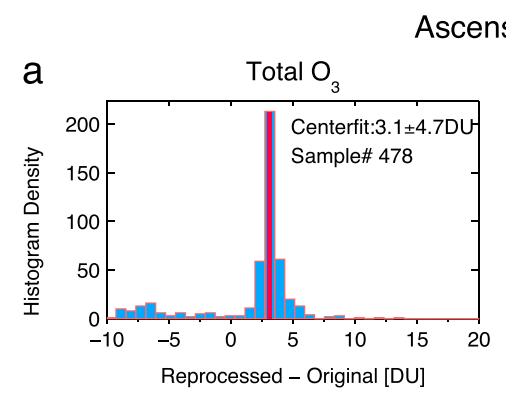

Ascension Is. Integrated $\mathrm{O}_{3}$ Column Amounts
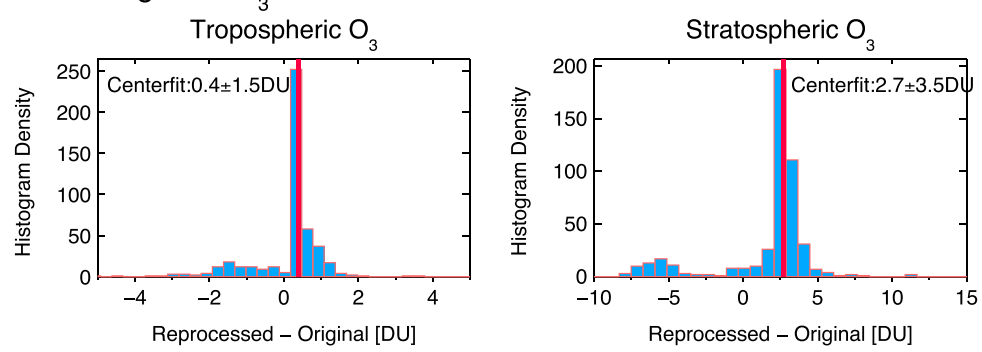

Natal, Brazil Integrated $\mathrm{O}_{3}$ Column Amounts
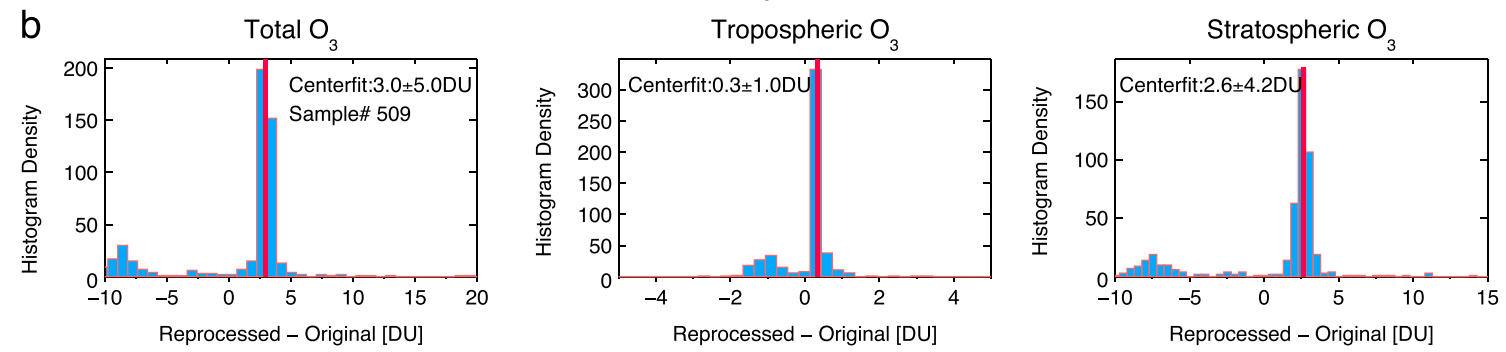

Irene, South Africa Integrated $\mathrm{O}_{3}$ Column Amounts
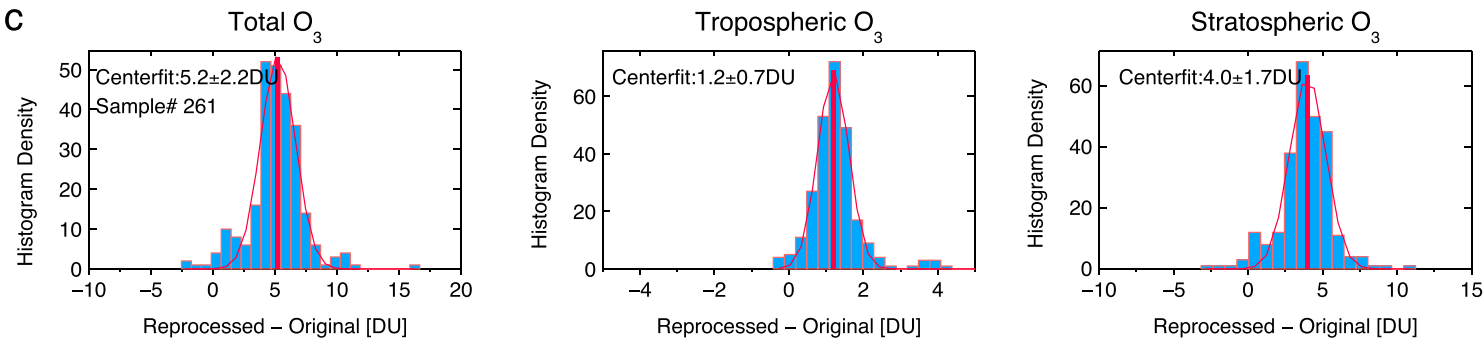

Watukosek-Java Integrated $\mathrm{O}_{3}$ Column Amounts
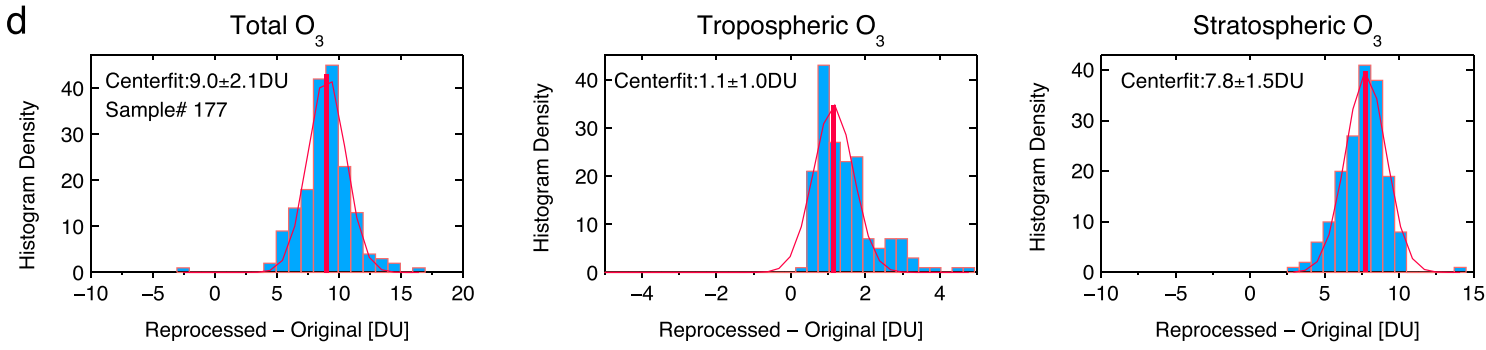

Figure 3. $(a-g)$ Histograms of the difference between the reprocessed and original profiles per site. Total integrated (ICO ${ }^{\text {total }}$ ) (left), tropospheric (middle), and stratospheric (right) $\mathrm{O}_{3}$ columns are shown. ICO $\mathrm{CO}^{\text {tolal }}$ amounts are integrated up to $5 \mathrm{hPa}$ with a $15 \mathrm{hPa}$ balloon burst limit. (c-f) Red curves in Figures $3 \mathrm{c}-3 \mathrm{f}$ are the Gaussian fit to the histograms that do not exhibit bimodel behavior. Red vertical lines indicate the centerfits of the distribution. Data gaps and pressure bursts at altitudes below $15 \mathrm{hPa}$ have led to sample size reductions of Figure 3a, 14\% at Ascension; Figure 3b, 7\% at Natal; Figure 3c, 15\% at Irene; Figure 3d, 30\% at Watukosek; Figure 3e, 36\% at Kuala Lumpur; Figure 3f, 15\% at La Réunion; and Figure 3g, 24\% at Hanoi.

Reprocessed Irene data in Figure $3 \mathrm{c}$ show that the largest impact is in the stratosphere (centerfit $=4.0 \pm 1.7 \mathrm{DU}$ ) contributing roughly $80 \%$ to the $5.2 \pm 2.2 \mathrm{DU}$ centerfit observed in ICO ${ }^{\text {total }}$. There are very few profiles where reprocessing has decreased ozone over Irene. The tropospheric column $\mathrm{O}_{3}$ increase of $1.2 \pm 0.7 \mathrm{DU}$ after reprocessing (Figure 3c, middle, centerfit) represents a 2-5\% change given typical values of 25-50 DU.

Reprocessing has the largest impact on the Watukosek data record, compared to all other sites. In Figure 3d there is an average $\mathrm{O}_{3}$ increase of $9.0 \pm 2.1 \mathrm{DU}$ in $\mathrm{ICO}^{\text {total }}$ with $86 \%$ of that enhancement affecting the 
e Kuala Lumpur, Malaysia Integrated $\mathrm{O}_{3}$ Column Amounts
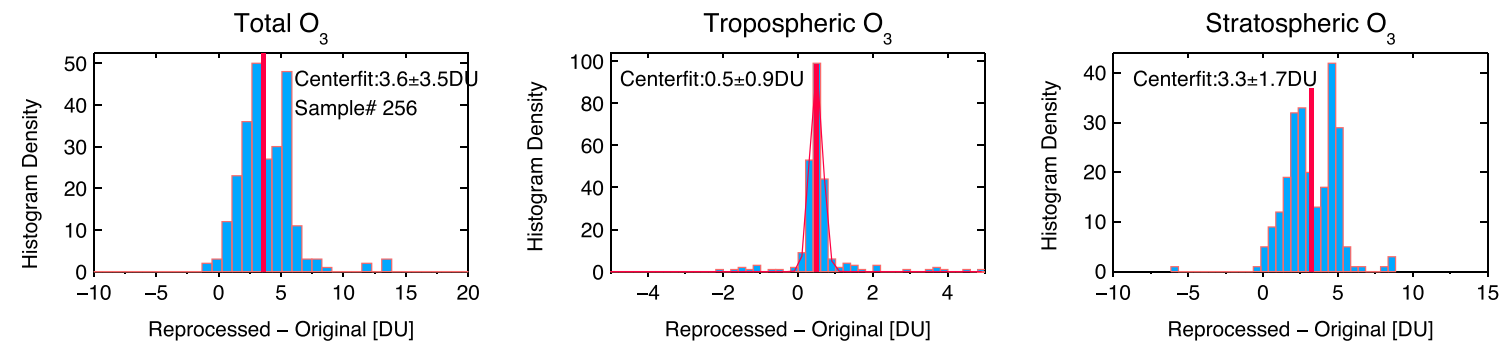

f

La Reunion Is., France Integrated $\mathrm{O}_{3}$ Column Amounts
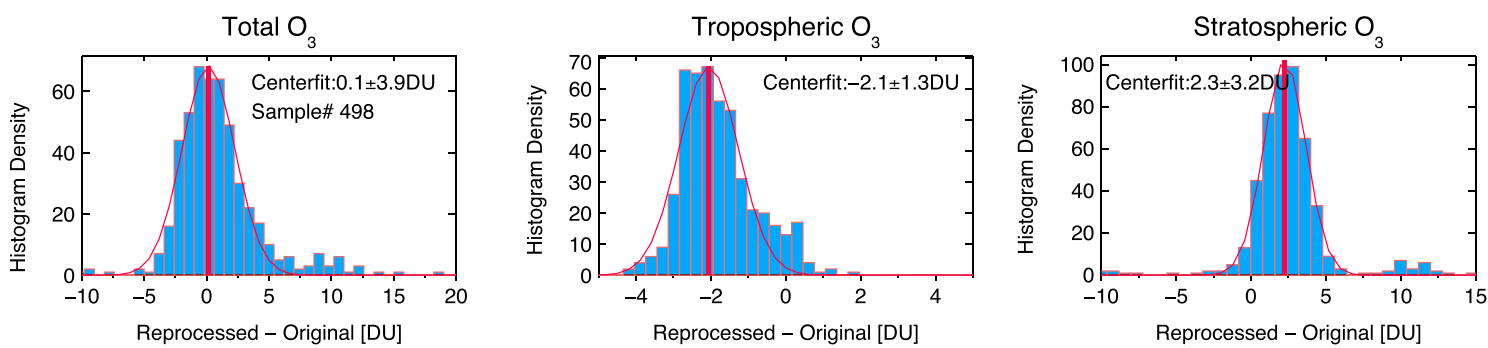

g

Hanoi, Vietnam Integrated $\mathrm{O}_{3}$ Column Amounts
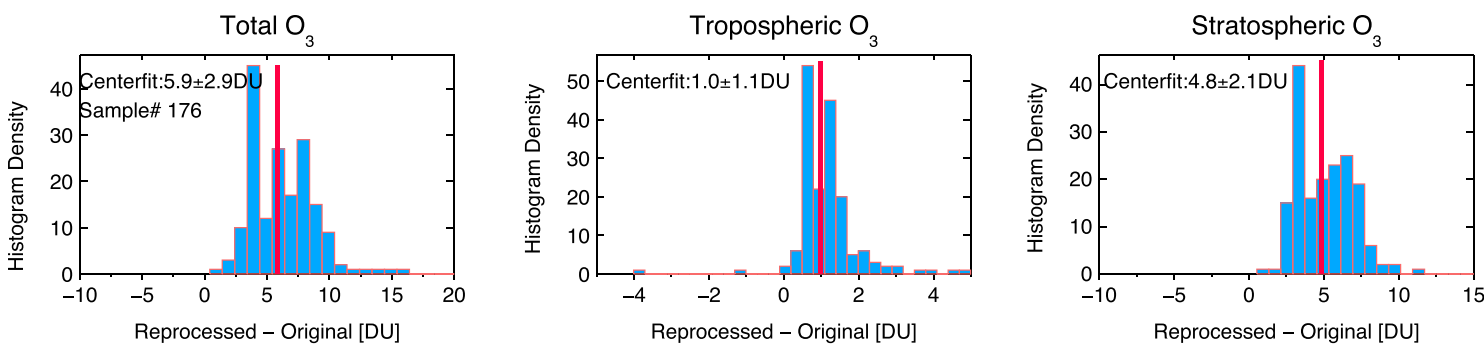

Figure 3. (continued)

stratosphere $(7.7 \pm 1.5 \mathrm{DU})$. This is due to a combination of the application of the $2 \%$ transfer function and the correction for high backgrounds (43\% of Watukosek's background currents exceed the $0.04 \mu \mathrm{A}$ threshold). Thompson et al. [2012] showed Watuoksek original data record underestimating the EP-TOMS satellite TCO overpasses by as much as $20 \%$. Thus, the significant increase in reprocessed $\mathrm{O}_{3}$ should reduce that bias (see section 6). Increases are also observed in the troposphere after reprocessing with most of the profile enhancements occurring between 0.5 and $2.0 \mathrm{DU}$. From Figure $3 \mathrm{~d}$, the tropospheric column $\mathrm{O}_{3}$ increase of $1.1 \mathrm{DU}$ after reprocessing (middle, centerfit) accounts for a 3-8\% change given typical values of $15-35 \mathrm{DU}$, while the $7.8 \pm 1.5 \mathrm{DU}$ stratospheric column $\mathrm{O}_{3}$ increase accounts for a 4-6\% change in the column for values ranging 130-215 DU (excluding the residual add-on).

The Kuala Lumpur data record (Figure 3e) show a $3.6 \mathrm{DU}$ increase in reprocessed ICO ${ }^{\text {total }}$ with an equally large uncertainty of $\pm 3.5 \mathrm{DU}$. This enhancement is observed mostly in the stratosphere (3.3 $\pm 1.7 \mathrm{DU})$. There is a bimodal distribution with peaks close together in $\mathrm{ICO}^{\text {total }}$ and stratospheric $\mathrm{O}_{3}$ (Figure 3e, right). This may be due to the change in the radiosonde model and software system. The first peak at around 2 DU in stratospheric $\mathrm{O}_{3}$ is concurrent with the use of the Vaisala RS80 model and DigiCora ${ }^{\circledR}$ MW15 software system, whereas the second peak at $\sim 5$ DU coincides with an update in April 2005 to the RS92 and DigiCora ${ }^{\circledast}$ MW41 system. The limited used of the Modem and Changfeng ozonesonde systems in the latter half of the data record show similar responses to reprocessing as the Vaisala RS92/ozonesonde system. There is a small cluster of elevated stratospheric $\mathrm{O}_{3}$ at 8-10 DU associated with the use of the Modem/ozonesonde system employed in 2010-2011. Figure A3 shows a large discontinuity in both the original and reprocessed stratospheric $\mathrm{O}_{3}$ data during this period that is not seen elsewhere in this time 
series. To maintain consistency and homogeneity, these data will be removed from the SHADOZ archive in the next version cycle.

The impact of reprocessing at La Réunion is complex. ICO ${ }^{\text {total }}$ differences in Figure $3 f$ show a large $1 \sigma$ standard deviation $( \pm 3.9 \mathrm{DU})$ relative to the centerfit that is close to zero due to a decrease in reprocessed tropospheric ozone $(-2.1 \pm 1.3 \mathrm{DU})$ and an equivalent increase in reprocessed stratospheric $\mathrm{O}_{3}(+2.3 \pm 3.2$ DU). This may be due to the application of the background currents which, as a constant offset, would decrease $\mathrm{O}_{3}$ throughout the profile. Although $I_{B}$ was recorded in the metadata, it was not applied to the original profile records. Ozonesonde cell currents, $I_{M}$, in the tropical troposphere are typically low (less than $1 \mu \mathrm{A}$ compared to $>3 \mu \mathrm{A}$ in the stratosphere) and are thus proportionally more affected by the magnitude of background currents, particularly if the latter is high (i.e., $>0.05 \mu \mathrm{A}$ threshold). The small secondary ICO ${ }^{\text {total }}$ maxima at around $10 \mathrm{DU}$, also seen in the stratosphere, is due to the application of the transfer functions (refer to Table 4). The $2.1 \mathrm{DU}$ decrease in tropospheric column $\mathrm{O}_{3}$ after reprocessing at La Réunion (Figure 3f, middle, centerfit) accounts for a 4-8\% decrease in the column amounts for typical values of 25-50 DU.

Hanoi data exhibit a bimodal distribution in the tropospheric and stratospheric $\mathrm{O}_{3}$ histograms (Figure 3g, middle and right, respectively) due to solution changes (Table 4). The first peak to the left of the centerfits coincides with reprocessed sondes that use the ENSCI0.5 standard pair in the second half of the data records (June 2009 to December 2015), while the higher second peak to the right of the centerfits corresponds to the reprocessed sondes using the ENSCI2.0 pair. Figure A2 shows a time series of reprocessed-original total, tropospheric, and stratospheric $\mathrm{O}_{3}$ column amounts at Hanoi, where one can see there is a pronounced difference in reprocessed ENSCI2.0 records versus ENSCI0.5 records. The Hanoi data, as with Watukosek, show significant enhancements of reprocessed ozone throughout the profile for records that use the $2 \%$ unbuffered solution.

How has reprocessing changed the profile shape and magnitude? This is illustrated in Figure 4 with comparisons of mean $\mathrm{O}_{3}$ profiles and $1 \sigma$ standard deviations before and after reprocessing at each site. Figure 4 shows that reprocessing enhances $\mathrm{O}_{3}$ in the stratosphere at all sites with minor to negligible changes in the troposphere, which is consistent with the results in Figure 3. In particular, enhanced $\mathrm{O}_{3}$ is observed after reprocessing at its maxima (Figure 4, middle panels). Ascension and Natal (Figures 4a and 4b) show the smallest $\mathrm{O}_{3}$ enhancements after reprocessing compared to the other sites. In general, the variability, denoted as the $1 \sigma$ standard deviation (Figure 4, right panels), is reduced in the reprocessed sondes. The exceptions are in the uppermost part of the profiles in Ascension (Figure 4a) and Watukosek (Figure 4d). La Réunion data, shown in Figure $4 \mathrm{f}$, are the only station to show a decrease in tropospheric $\mathrm{O}_{3}$ as a result of applying background currents. Hanoi and Watukosek data show enhanced reprocessed $\mathrm{O}_{3}$ throughout the profile that is particularly pronounced in the lower stratosphere and the lowermost troposphere (Figures $4 \mathrm{~d}$ and $4 \mathrm{~g}$, respectively, middle), likely dominated by background current corrections and the addition of $2 \%$ to entire profile for the ENSCI2.0 records which, for Hanoi, accounts for $51 \%$ of the total record and the entire data set at Watukosek. Irene and Kuala Lumpur also show an increase in tropospheric $\mathrm{O}_{3}$ after reprocessing, probably due to the application of the monthly pump temperature climatology (Figures $4 \mathrm{c}$ and $4 \mathrm{e}$, respectively). In these same figures, the $1 \sigma$ standard deviation in the lowermost troposphere is slightly higher (Figures $4 \mathrm{c}$ and $4 \mathrm{e}$, right).

Overall, there are negligible to modest changes in ozone after reprocessing. Ascension and Natal display the small reprocessing impact with negligible changes on the order of a few percent in ICO ${ }^{\text {total }}$. Irene, Watukosek, and Hanoi display modest changes in $\mathrm{ICO}^{\text {total }}$ of up to $5 \%$. Modest changes of up to $8 \%$ in tropospheric $\mathrm{O}_{3}$ are observed at La Réunion and Watukosek, given typical values, and up to $6 \%$ increases in stratospheric $\mathrm{O}_{3}$ are observed at Watukosek and Hanoi.

\section{Comparisons With Satellite Measurements}

For a first evaluation of reprocessing impacts we use satellite overpass TCO from NASA's Earth Probe Total Ozone Mapping Spectrometer (TOMS) [McPeters et al., 1998], Ozone Monitoring Instrument (OMI) [Levelt et al., 2006], and Microwave Limb Sounder (MLS) [Waters et al., 2006]. OMI and MLS are on board the NASA Aura spacecraft (https://aura.gsfc.nasa.gov/). TOMS version (v) 8.5 is data from the older generation 
a

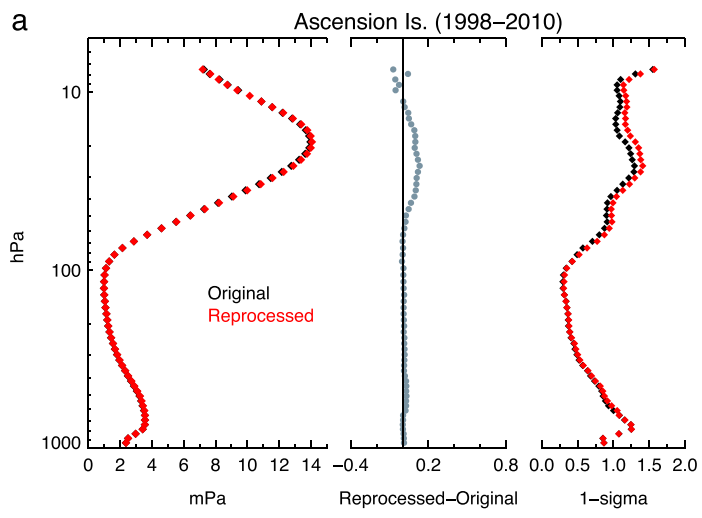

C

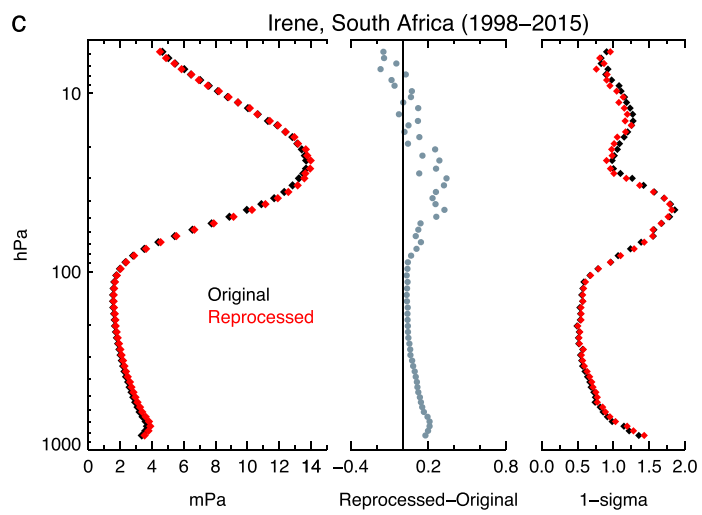

e
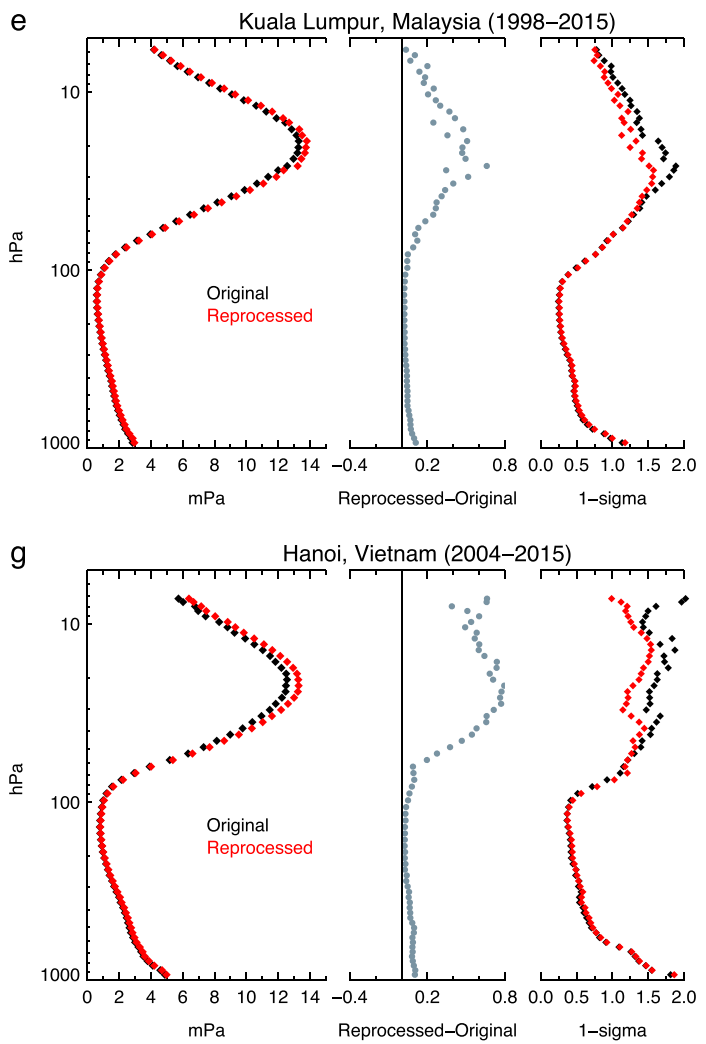

b

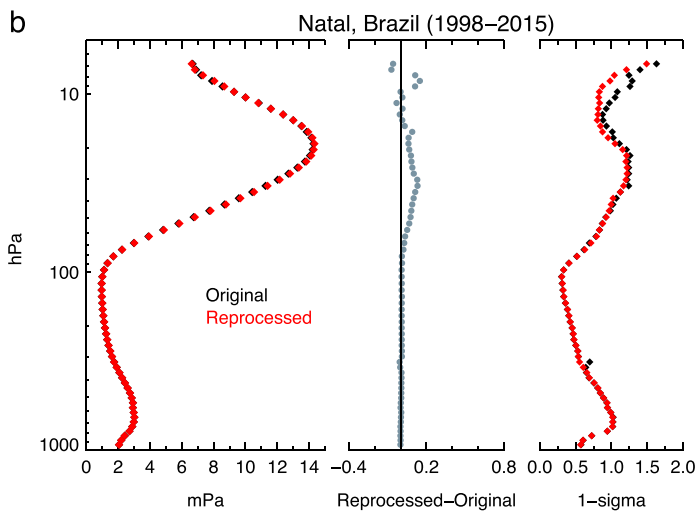

d

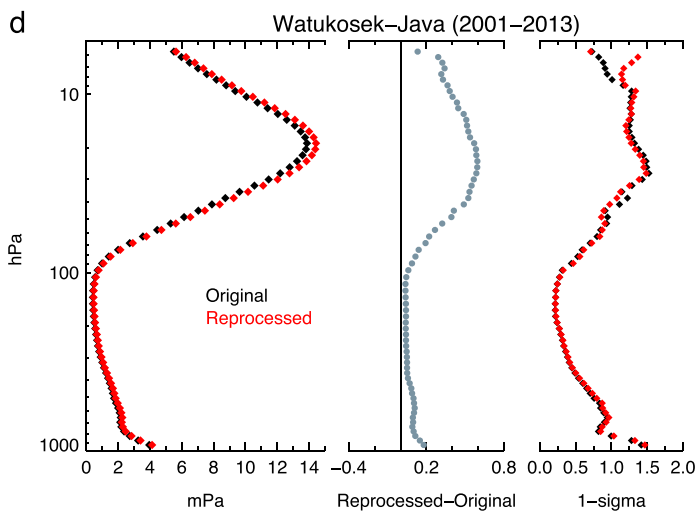

f

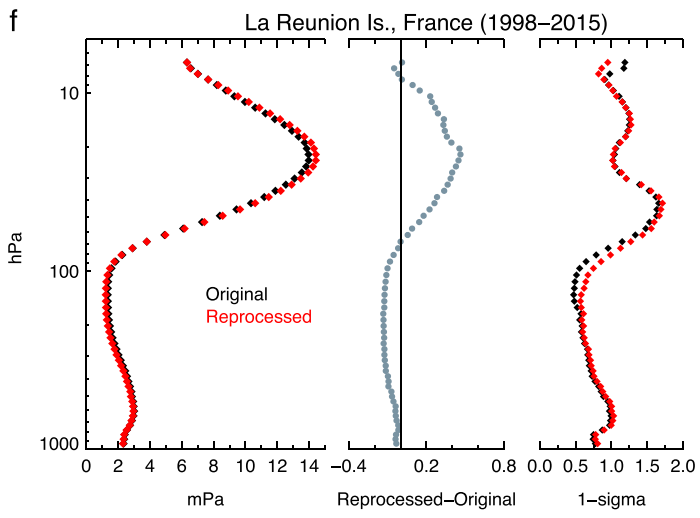

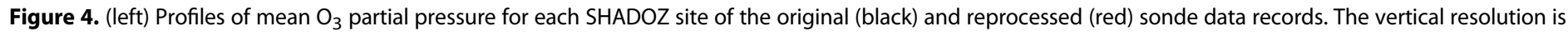

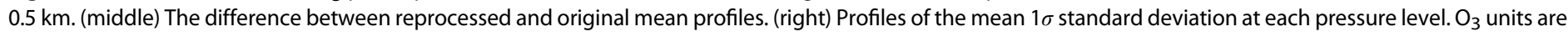
all in $\mathrm{mPa}$. 

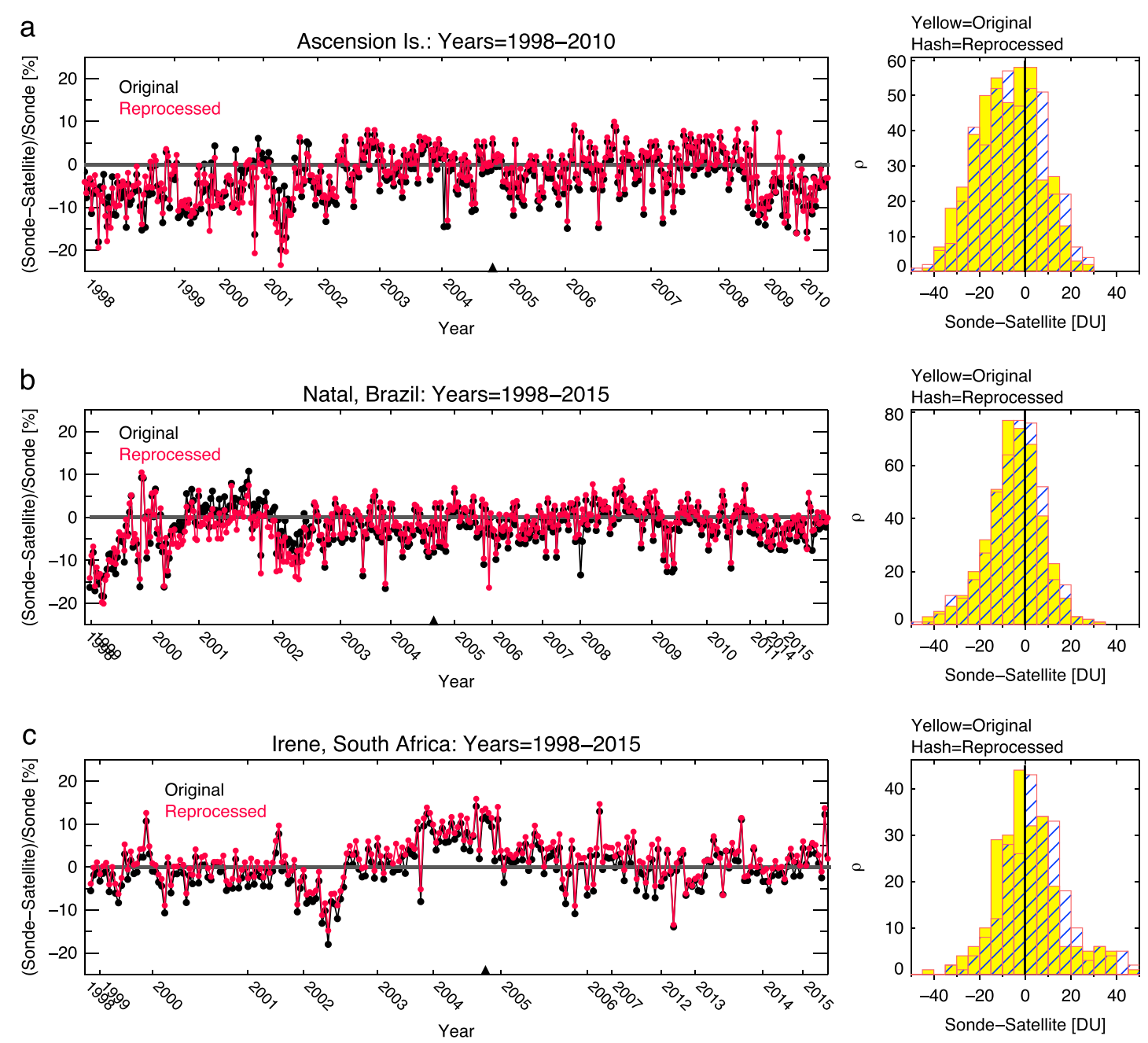

Figure 5. Time series of the percent difference in TCO between sondes and TOMS/OMI overpasses: reprocessed sondes in red and original in black (left column). Right column is the associated histograms of the difference for (a) Ascension Is., (b) Natal, note the 2012-2013 data gap, (c) Irene, note the 2008-2011 data gap, (d) Watukosek, (e) Kuala Lumpur, green colored years denote the use of the Modem/ozonesonde system, ( $\mathrm{f}$ La Réunion, and (g) Hanoi. Ozonesonde TCO are calculated using the McPeters and Labow [2012] add-on ozone climatology for balloon bursts above $15 \mathrm{hPa}$ and capped at $5 \mathrm{hPa}$. The transition from TOMS to OMI overpasses occurs in September 2004 and is marked by the black triangle on the $x$ axis. Results are plotted in sequence, accounting for the uneven spacing of the years on the $x$ axis.

nadir-viewing spectrometer that operated from 1996 through 2005, overlapping about 1 year with OMI (September 2004 to present; v3 is used). Overpass data from OMI and MLS are available at the Aura Validation Data Center (AVDC): http://avdc.gsfc.nasa.gov. TOMS overpass column values are downloaded from the NASA Goddard Earth Science Data and Information Services Center (GES-DISC) archive: http:// disc.gsfc.nasa.gov. The version 8 TOMS algorithm was used to process OMI data to maintain continuity between the two records [McPeters et al., 2015]. OMI and TOMS data are filtered for reflectivity (cloudiness) greater than $60 \%$ and overpasses located over $200 \mathrm{~km}$ from the site location. MLS v4.2 overpasses are within $\pm 5^{\circ}$ latitude and $\pm 8^{\circ}$ longitude of the site's location. These instruments have a local overpass time of around 1330 that coincides with a few SHADOZ sites launch times (refer to Table 1). TOMS and OMI instruments measure the solar radiation backscattered in the ultraviolet to visible wavelength range, providing global coverage of TCO with horizontal resolutions at nadir of $1.00 \times 1.25^{\circ}$ latitude/longitude for TOMS and $13 \times 24 \mathrm{~km}$ for OMI. The MLS instrument is a limb-viewing microwave radiometer, providing daily profile measurements of $\mathrm{O}_{3}$ with a vertical resolution of about $3 \mathrm{~km}$ in the stratosphere and a horizontal resolution of 200-300 km [Waters et al., 2006]. MLS v4.2 is used at pressure levels between $215 \mathrm{hPa}$ and $5 \mathrm{hPa}$. Uncertainties are reported by Livesey et al. [2016]. All three of these instruments have a local overpass time of $\sim 1330$ that coincides with a few SHADOZ sites launch times (refer to Table 2). 
d
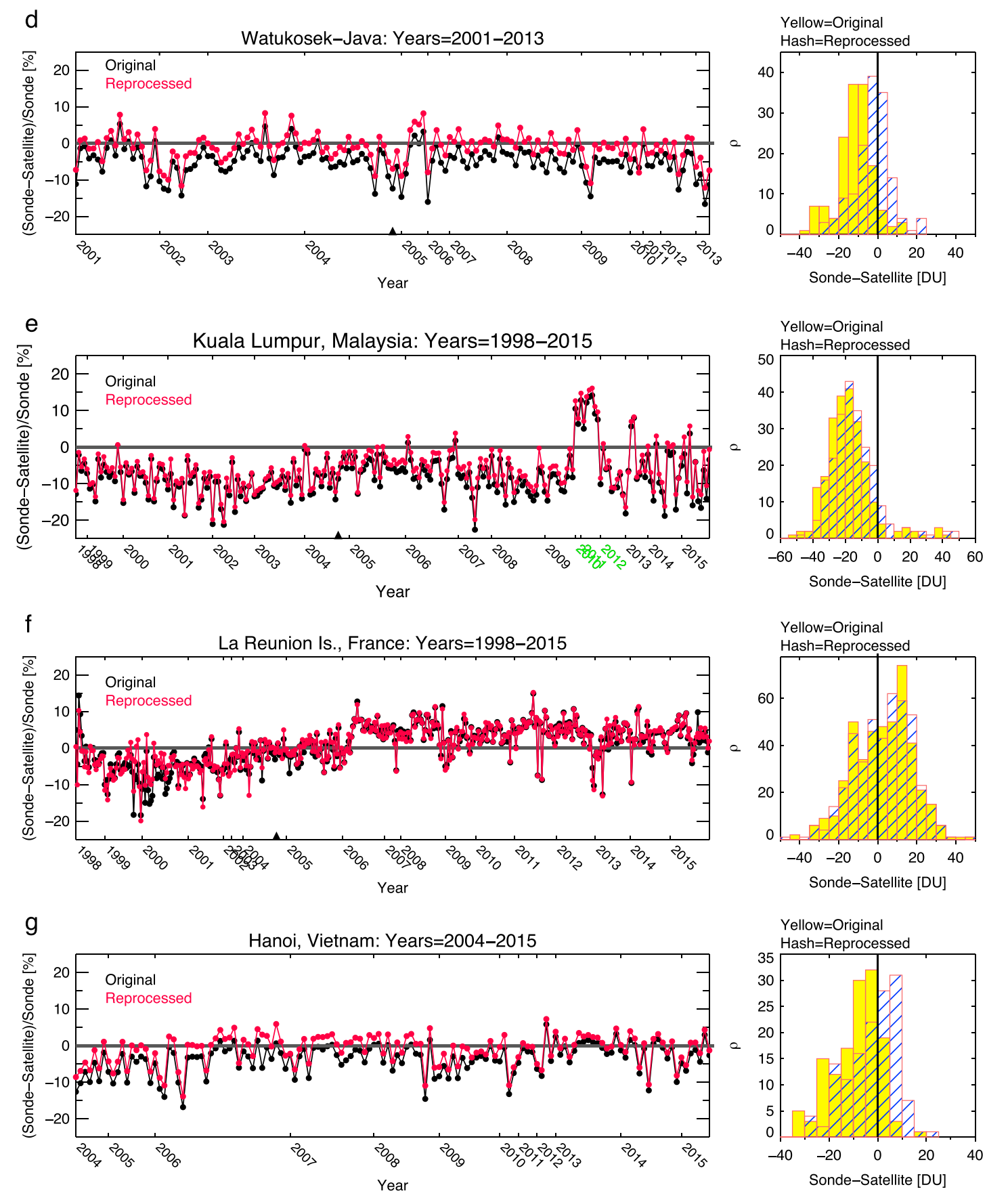

Figure 5. (continued)

\subsection{Comparisons With TOMS and OMI}

The change in agreement, if any, between the reprocessed ozonesonde TCO and TOMS and OMI overpasses (in this section simply referred to as satellite overpasses) is illustrated in Figure 5 as percentage differences relative to the sondes. Histograms (Figure 5, right column) show the difference between original/reprocessed ozonesonde TCO and satellite overpasses to examine changes and variability in the distribution. These statistics are summarized in Table 5 with the root-mean-square error (RMSE), correlations, and biases with the satellites. We use the McPeters and Labow [2012] 1988-2010 MLS/ozonesonde monthly climatologies to calculate the $\mathrm{O}_{3}$ residual from balloon burst to the top of the atmosphere to get the ozonesonde $\mathrm{TCO}$, i.e., $\mathrm{ICO}^{\text {total }}+\mathrm{O}_{3}$ residual. 
Table 5. Statistics Summarizing the Relationship Between the TCO From the Combined TOMS/OMI Overpass Data and Both Original and Reprocessed Ozone Data Records Illustrated in Figure 5 (Time Series, Left Column) ${ }^{\text {a }}$

\begin{tabular}{|c|c|c|c|c|c|c|c|c|c|}
\hline \multirow[b]{2}{*}{ Site } & \multirow[b]{2}{*}{ SN } & \multicolumn{2}{|c|}{ RMSE (DU) } & \multicolumn{2}{|c|}{ Correlation (DU) } & \multicolumn{2}{|c|}{ Centerfit $\pm 1 \sigma$ (Sonde-Satellite), (DU) } & \multicolumn{2}{|c|}{ Bias (DU) } \\
\hline & & Orig. & Repr. & Orig. & Repr. & Orig. & Repr. & Orig. & Repr. \\
\hline Ascension & 429 & 15.8 & 15.5 & 0.62 & 0.62 & $-7.9 \pm 13.6$ & $-5.4 \pm 14.3$ & 104.3 & 110.8 \\
\hline Natal & 448 & 13.1 & 12.9 & 0.63 & 0.63 & $-3.9 \pm 12.1$ & $-2.6 \pm 12.2$ & 69.1 & 69.7 \\
\hline Irene & 240 & 14.2 & 15.8 & 0.73 & 0.73 & $-1.1 \pm 14.2$ & $4.1 \pm 14.7$ & 56.7 & 59.1 \\
\hline Watukosek & 145 & 14.9 & 10.0 & 0.64 & 0.62 & $-10.6 \pm 9.3$ & $-1.3 \pm 9.6$ & 50.8 & 44.7 \\
\hline Kuala Lumpur & 228 & 23.1 & 20.7 & 0.54 & 0.52 & $-19.9 \pm 14.5$ & $-16.6 \pm 15.1$ & 50.2 & 51.3 \\
\hline La Réunion & 440 & 15.1 & 14.9 & 0.68 & 0.70 & $4.0 \pm 14.9$ & $4.7 \pm 14.5$ & 62.6 & 63.8 \\
\hline Hanoi & 137 & 13.1 & 10.3 & 0.88 & 0.89 & $-6.3 \pm 9.8$ & $0.7 \pm 10.1$ & 44.5 & 46.6 \\
\hline
\end{tabular}

${ }^{\mathrm{a}}$ Biases are the $y$ intercept from the ordinary least squares bisector where ozonesondes are the dependent variable. Gaussian centerfits and $1 \sigma$ standard deviations are determined from the frequency distribution of the difference between sonde and satellite overpasses, i.e., sonde-satellite TCO shown in Figure 5 (right column). SN is the sample number of profiles remaining after satellite overpasses have been filtered for clouds $>60 \%$ and distance $>200 \mathrm{~km}$ from the station location.

Ascension and Natal (Figures $5 \mathrm{a}$ and $5 \mathrm{~b}$ ) use the LMS/ozonesonde system and show minor overall changes in Figures $3 a$ and $3 b$. As expected, the overall impact of reprocessing was a modest change to the TCO centerfit ( $3 \mathrm{DU})$. From Table 5 we observe negligible changes in the correlations and RMSE ( $<1 \mathrm{DU})$, and comparable $1 \sigma$ and biases. The time series in Figures $5 \mathrm{a}$ and $5 \mathrm{~b}$ show a decrease in the satellite low bias relative to the reprocessed sondes (red), also reflected in the positive shift in the distribution of the reprocessed sonde-satellite histograms (right, hashed). Percentage differences are reduced in the early part of the Ascension record (1998-1999) where transfer functions had been applied (Figure 5a, red), but biases are reported to be higher by $6.5 \mathrm{DU}$ compared to the original data (refer to Table 5). The observed change in agreement at Ascension since the end of 2008 (Figure 5a) coincides with a change from the NASA/WFF in-house built "Unisonde" software system (E. T. Northam, personal communication, 2017) to the VIZ W-900 Zeemet system. The Natal time series from 1998 to mid-2000 in Figure $5 \mathrm{~b}$ shows large variability in the agreement with TOMS overpasses that correspond to the use of the older generation VIZ Manufacturing Inc. (later Sippican Inc.) Mark II LORAN-C Microsonde radiosonde model (MK2LORAN-C) and VIZ Zeemet W-9000 ground station/software. This irregularity in agreement disappears by August 2000 when Natal upgraded their radiosonde model and system (Sip GPS LOS-T radiosonde model and VIZ Zeemet W-900 Zeemet software system). No further inhomogeneities are observed even though the LMS/ozonesonde system made additional upgrades in the latter half of the data records. We speculate that uncorrected pressure offsets may be a contributing factor to the discontinuity and irregularity in the data records prior to August 2000.

The discernible change in agreement due to reprocessing at Natal between mid-2000 and mid-2002 is due to the application of the transfer functions to compensate for solution changes. The statistics in Table 5 do not change significantly for comparisons without transfer functions (not shown).

Results from Irene in Figure $5 c$ show that the overall higher bias in the satellite overpasses relative to the original records (black) is reduced after reprocessing (red). In fact, the associated histograms reveal that reprocessing shifts the distribution of the sonde-satellite difference from a centerfit of $-1.1 \pm 14.2 \mathrm{DU}$ to $+4.1 \pm 14.7 \mathrm{DU}$, signifying that a substantial fraction of the reprocessed sonde data are high biased relative to the satellite overpasses. The magnitude of this change is consistent with results shown in Figure $3 c$. The relationship of the reprocessed data to satellites is still comparable to that of the original data records: Table 5 shows insignificant differences in the RMSE and $1 \sigma$ standard deviation and no change in the correlation. The bias with satellites, however, increases by $2.4 \mathrm{DU}$ as a result of increased ozone everywhere after reprocessing. For Irene, Figure $5 \mathrm{c}$ includes an interesting feature in 2004 where the satellite becomes significantly low biased relative to both sonde records at around $+10 \%$. This discontinuity does not coincide with known changes in the Irene radiosonde/ozonesonde system or operating procedures, and it disappears in 2005. The second half of 2004 marks the TOMS to OMI transition (black triangle), but this discontinuity in the satellite comparison does not appear at any of the other sites in Figure 5. The 1998-2006 Irene record used monthly mean pump temperatures (Figure A1) which were missing in the original data files. Apart from the noticeable enhanced positive agreement in 2004 at around $+10 \%$ observed in Figure 5c, there are no prominent discontinuities between this historic time period and the rest of the record. 


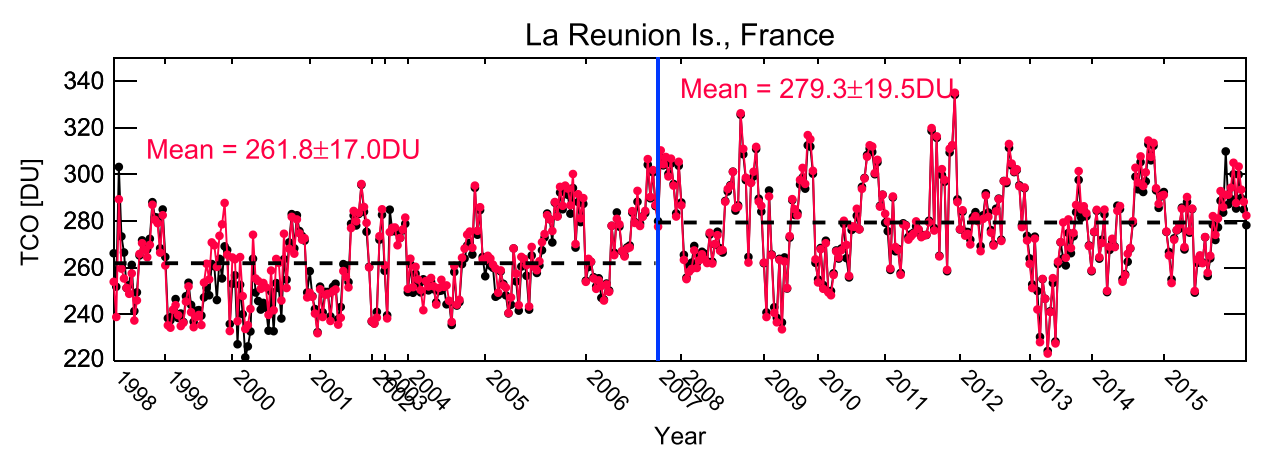

Figure 6. Time series of La Réunion original (black) and reprocessed (red) TCO. Solution change from $0.5 \%$ half buffer to a full buffer formula occurred in 2007 (blue line). The horizontal dashed lines indicate the mean reprocessed TCO for the two periods. Associated mean and $\pm 1 \sigma$ values of the reprocessed TCO are included (red).

There are also no discernible discontinuities between the original and reprocessed data comparisons with the satellite overpasses; this demonstrates the suitability of using the monthly pump temperature climatologies, where necessary.

The original time series at Watukosek show that satellites measure more TCO than the sondes (Figure $5 \mathrm{~d}$, black). From Table 5, the centerfit shows that this discrepancy is $-10.6 \pm 9.3 \mathrm{DU}$ and is reduced significantly, to $1.3 \pm 9.6 \mathrm{DU}$, after reprocessing. The RMSE is reduced by $\sim 33 \%$, and correlations, $1 \sigma$, and biases are comparable to the original. This large response in reprocessing is also reflected in the associated histograms in Figure $5 \mathrm{~d}$ where the distribution shifts from a negative range of 5-20 DU in the original comparisons (yellow, highest frequencies) to $-10 \mathrm{DU}$ to $+5 \mathrm{DU}$ about the centerfit (hashed). These results support the " $2 \%$ addition" procedure for the ENSCI2.0 data and high background current correction.

Reprocessing at Kuala Lumpur has reduced the difference between sonde and satellites as shown in Figure 5e. Table 5 shows that the centerfit of the sonde-satellite time series is reduced by $3.3 \mathrm{DU}$ after reprocessing. The RMSE shows slight improvement (20.7 DU compared to 23.1 DU using the original data), and the $1 \sigma$ and biases are close to the original values. The correlation is slightly worse when compared to the reprocessed data that are likely influenced by the persistent low bias in the satellite overpasses from 2010 through 2011 (Figure 5e, $x$ axis years in green). This time period coincides with the use of the Modem/ozonesonde system. These remaining profiles, after filtering for outliers, still suggest an unknown error in the profile measurements. Outside of this anomalous period satellite TCO is consistently higher than sondes. This discontinuity is also observed in the original and reprocessed time series of stratosphere column $\mathrm{O}_{3}$ (Figure A3). As with Irene, monthly mean pump temperatures were used to reconstruct the 1998-2005 Kuala Lumpur profiles and there are no noticeable discontinuities within this period between the original and reprocessed data sets (refer to Figure 5e).

The results at La Réunion in Figure $5 f$ show that reprocessing has a negligible impact on the relationship between satellites and sonde TCO. This is may be due to a cancellation of changes illustrated in Figures $3 f$ and $4 \mathrm{f} \mathrm{that} \mathrm{show} \mathrm{a} \mathrm{decrease} \mathrm{in} \mathrm{reprocessed} \mathrm{ozone} \mathrm{in} \mathrm{the} \mathrm{troposphere} \mathrm{relative} \mathrm{to} \mathrm{the} \mathrm{original} \mathrm{data} \mathrm{and} \mathrm{an}$ increase in the stratosphere by similar amounts. Transfer functions applied between 1999 and 2000 contribute to an improvement in the reprocessed sonde-satellite agreement (Figure $5 f$, red). What does stand out is the transition from satellites mostly retrieving higher TCO than the sonde from 1998 through 2006 to mostly underestimating sondes from 2007 through 2015. This pronounced discontinuity in the agreement occurs in both the original and reprocessed time series and coincides with a change in solution from $0.5 \%$ half buffer to a full buffer formula. Johnson et al. [2002] performed sensing solution sensitivity tests to evaluate the ozone response to different sensing solution concentrations and $\mathrm{pH}$ buffers. They found a hysteresis effect of $5-7 \%$ excess ozone with increasing buffer concentrations at low pressures. This is evident in Figure 6 which shows how the change in solution formulae affects the TCO measurements at La Réunion. During the period ENSCI0.5 sondes were flown, the mean reprocessed TCO is $261.8 \pm 17.0$ DU which then jumps to $279.3 \pm 19.5 \mathrm{DU}$ when the $0.5 \%$ full buffer formula is introduced (Figure 6, blue line): a significant difference of $\sim 18$ DU. Original TCO show the same discontinuity (black). Time series of 

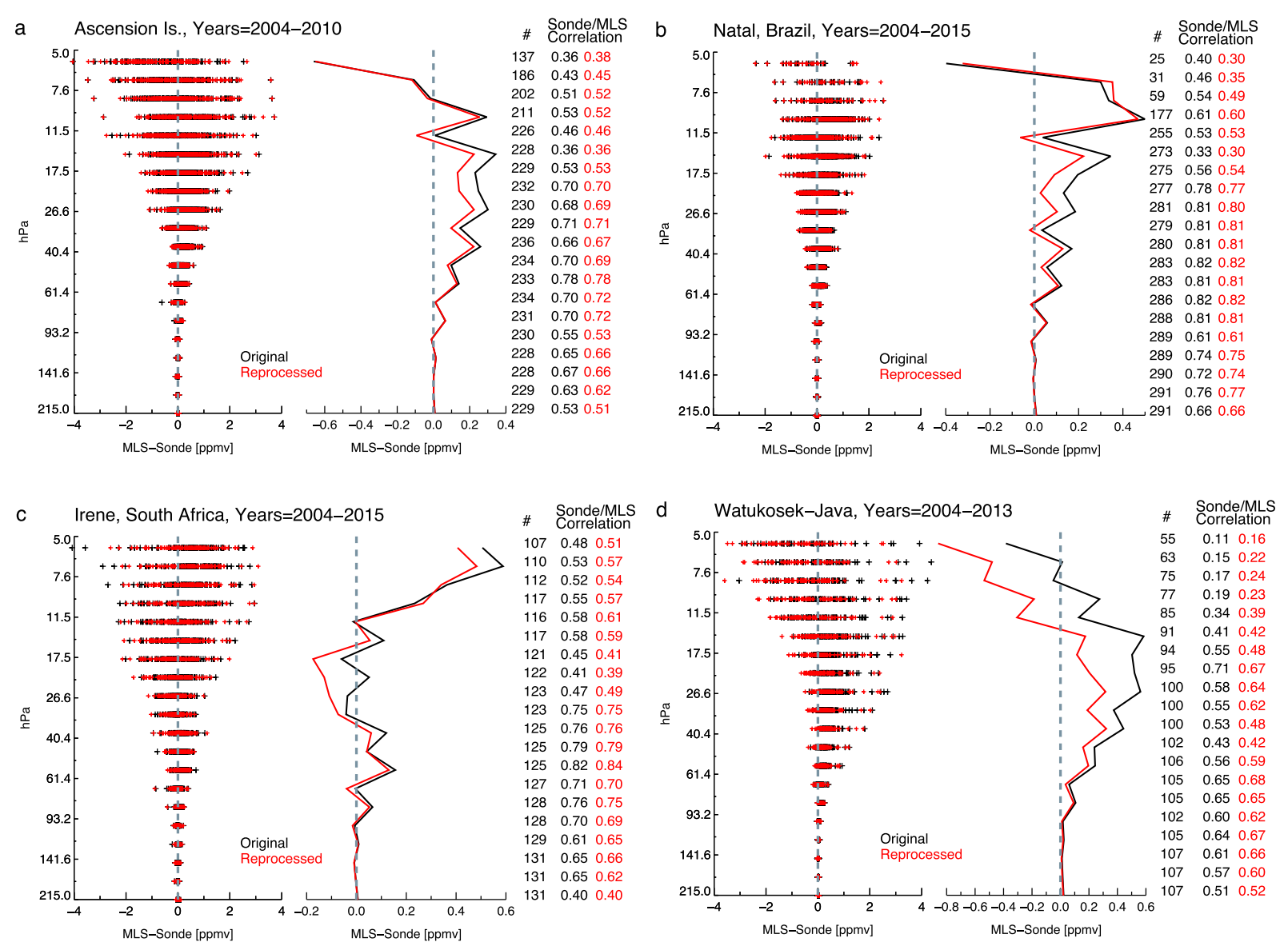

Figure 7. $\mathrm{O}_{3}$ VMR (in ppmv) profile comparisons of MLS-Sonde at (a) Ascension, (b) Natal, (c) Irene, (d) Watukosek, (e) Kuala Lumpur, (f) La Réunion, and (g) Hanoi. $\mathrm{O}_{3}$ VMR are interpolated to the standard MLS pressure levels between $215 \mathrm{hPa}$ and $5 \mathrm{hPa}$. Left panels are the individual profile differences for original (black) and reprocessed (red) profiles. Right panels are the resulting mean profile of those differences. Sample number (\#) and correlations of original sondes versus MLS (black), and reprocessed sondes versus MLS (red) at each pressure level are shown (right). Hanoi in Figure $7 \mathrm{~g}$ separates the comparisons for reprocessed ENSCI0.5 (red) and ENSCI2.0 records (blue). MLS measurements start in September 2004.

tropospheric and stratospheric column ozone (not shown) that reveal the discontinuities seen in Figures $5 \mathrm{f}$ and 6 are observed only in the stratosphere. Thus, calculating stratospheric trends with the La Réunion data set is not recommended. Table 5 statistics for La Réunion show minor improvements with reprocessing.

Reprocessing of Hanoi data has led to a decrease in the high bias of the satellites with the sonde by 5.6 DU (Table 5, centerfits). We observe in Figure 5g (right) that reprocessing has shifted the distribution of the sonde-satellite differences toward zero (hashed), particularly for the ENSCI2.0 records (blue). Like the Kuala Lumpur record, the RMSE is lower after reprocessing and the $1 \sigma$ and biases are similar to the original values. This decrease is mostly attributed to the $2 \%$ adjustment for the ENSCI2.0 records.

\subsection{Profile Comparisons With MLS}

The impact of reprocessing on the SHADOZ vertical profiles is further evaluated by comparing $\mathrm{O}_{3}$ volume mixing ratios (VMR) with MLS overpasses in the lower and middle stratosphere between $215 \mathrm{hPa}$ and $5 \mathrm{hPa}$ pressure levels. Ozone VMR profiles are interpolated to the standard MLS pressure levels with results shown in Figure 7, along with correlations between the sonde and MLS before (original in black) and after reprocessing (red) at each pressure level. Jiang et al. [2007] showed negligible differences between fitting of the ozonesonde profiles to the MLS ozone retrieval grid and the use of MLS averaging kernels to the 
e

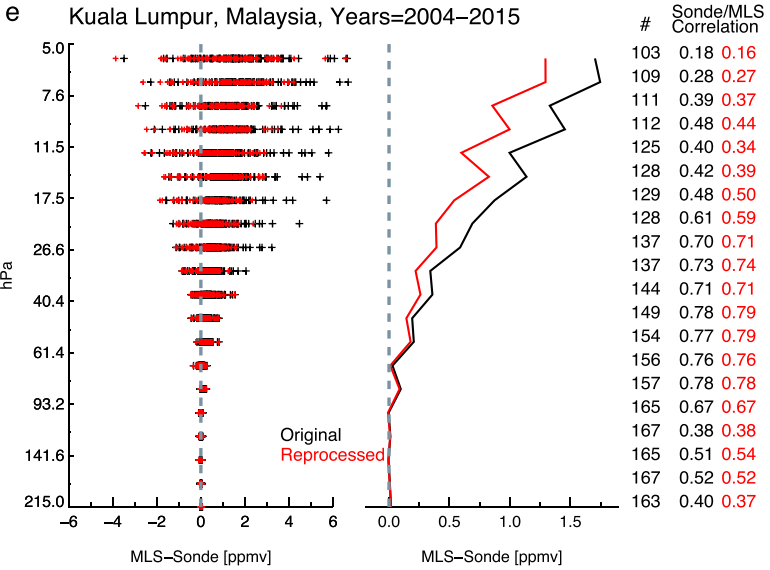

f La Reunion Is., France, Years=2004-2015 \# Sonde/MLS

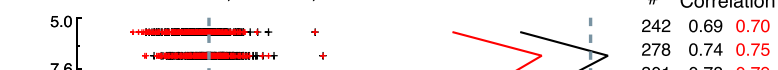
$\begin{array}{lll}278 & 0.74 & 0.75 \\ 301 & 0.78 & 0.79\end{array}$ $\begin{array}{llll}323 & 0.79 & 0.79\end{array}$ $\begin{array}{llll}335 & 0.78 & 0.78\end{array}$ $\begin{array}{llll}342 & 0.74 & 0.74\end{array}$ $\begin{array}{llll}342 & 0.74 & 0.74 \\ 347 & 0.66 & 0.67\end{array}$ $\begin{array}{lll}347 & 0.66 & 0.67 \\ 345 & 0.60 & 0.59\end{array}$ $\begin{array}{llll}345 & 0.60 & 0.59\end{array}$ $\begin{array}{llll}351 & 0.72 & 0.72\end{array}$ $\begin{array}{llll}351 & 0.72 & 0.72\end{array}$ $\begin{array}{llll}353 & 0.82 & 0.82\end{array}$ $\begin{array}{lll}356 & 0.84 & 0.84\end{array}$ $\begin{array}{llll}353 & 0.82 & 0.82\end{array}$ $\begin{array}{llll}353 & 0.82 & 0.82\end{array}$ $\begin{array}{llll}354 & 0.79 & 0.79\end{array}$ $\begin{array}{lll}355 & 0.61 & 0.61\end{array}$ $\begin{array}{llll}355 & 0.59 & 0.60\end{array}$ $\begin{array}{llll}357 & 0.60 & 0.60\end{array}$ $\begin{array}{lll}357 & 0.60 & 0.60 \\ 355 & 0.50 & 0.51\end{array}$ $\begin{array}{lll}356 & 0.49 & 0.50\end{array}$

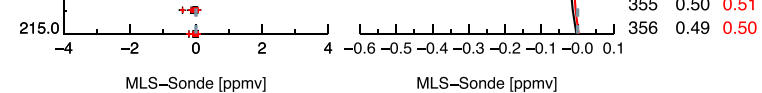

g Hanoi, Vietnam, Years $=2004-2015$

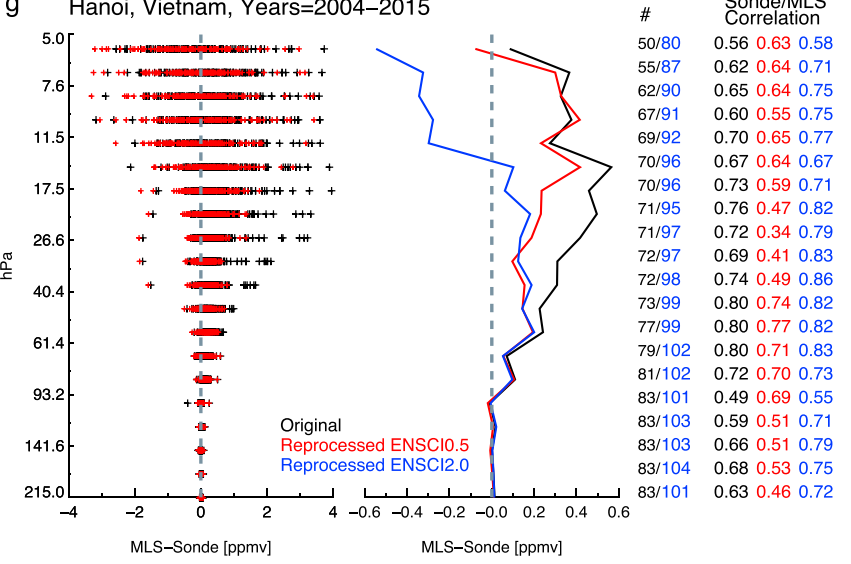

Figure 7. (continued)

ozonesonde data after fitting to the MLS grid. The pattern of agreement between MLS and sondes differs among stations; within each station the agreements vary at each pressure level.

Overall, improvement in the MLS agreement with sondes after reprocessing is seen in the $50 \mathrm{hPa}-10 \mathrm{hPa}$ pressure range at Ascension, Natal, Irene, Watukosek, Kuala Lumpur, and Hanoi (Figures 7a-7e, and 7g, middle, red profiles). Note that the MLS $1 \sigma$ standard deviations are generally higher than both the original and reprocessed sonde values, with the exception of Irene and Kuala Lumpur (refer to Table S1 in the supporting information). This is a consequence of using the monthly mean pump temperature profiles where further inspection of the sonde data reveal that the highest $1 \sigma$ values occur during these periods; refer to Table 4 for dates when monthly pump temperature climatologies were used at Irene and Kuala Lumpur.

Correlations between sondes and MLS overpasses shown in Figure 7 do not differ significantly after reprocessing, except at Watukosek and Hanoi (for which the $2 \%$ unbuffered solution was used, Figure $7 \mathrm{~g}$, blue). In particular, at pressures less than $10 \mathrm{hPa}$, the MLS-sonde differences among sites are highly variable and large (Figure 7, right panels). This is also a region characterized by significantly reduced sample sizes. In our TCO and ICO ${ }^{\text {total }}$ calculations we had chosen to cap pressures to $5 \mathrm{hPa}$ to include as much of the reprocessed ozone profile as possible for our evaluation. When we perform the same analysis with a pressure cutoff at $10 \mathrm{hPa}$ the main observable difference is a decrease in the $1 \sigma$ standard deviations, particularly in the stratosphere. This is consistent with the large $\mathrm{O}_{3}$ variability we observe in the individual profiles above $12 \mathrm{hPa}$ (Figure 7, left panels). Reprocessing has not improved measurement accuracy above $10 \mathrm{hPa}$; therefore, it is recommended to limit integrated total $\mathrm{O}_{3}$ to a pressure cutoff of $10 \mathrm{hPa}$. Stations using the $2 \%$ unbuffered solution (Watukosek and Hanoi in Figures $7 \mathrm{~d}$ and $7 \mathrm{~g}$, respectively) measure higher $\mathrm{O}_{3}$ than $\mathrm{MLS}$ at pressures 
less than $10 \mathrm{hPa}$. In contrast, Irene (Figure 7c, right) uses a 1\% buffered solution and sondes measure lower than MLS at the same pressures. All three sites use Vaisala radiosondes; thus, this inconsistency does not originate from instrumental differences. Johnson et al. [2002] PCF are between 2\% (at $100 \mathrm{hPa}$ ) and 15\% (at $5 \mathrm{hPa}$ ) higher than both Komhyr PCF and can account for the much higher $\mathrm{O}_{3}$ observed at Watukosek and Hanoi, relative to MLS. La Réunion is the only site showing $\mathrm{O}_{3}$ from sondes higher than MLS (Figure 7f, right), consistent with Johnson et al. [2002] study regarding a hystersis effect due to the buffering of the solution. Ascension and Natal, which also use a $1 \%$ buffered solution, show a mixture of agreements above $10 \mathrm{hPa}$ that cannot be explained by the influence of the buffer on the sensor response alone (Figures 7a-7b, middle).

The large variability of the sonde measurements at low pressures may be due to fluctuations in the sensor's pump efficiency and the inaccuracy of the standard PCF. At pressures lower than $100 \mathrm{hPa}$, the ECC pump efficiency starts to decrease and PCFs from lookup tables are applied to compensate for the deficiency in the sensor performance [Komhyr, 1967, 1969, 1986, Komhyr et al., 1995; Johnson et al., 2002; Smit et al., 2014] ( $\psi$ in equation (1)). The standard Komhyr [1986], Komhyr et al. [1995] PCF are based on small sample sizes ([e.g., Komhyr et al., 1995] PCF results are based on 13 profiles), the SPC manufacturer type only, and models older than the current SPC 6A. Moreover, they greatly underestimate the true pump efficiencies due to the complication of the buffer concentrations that are most sensitive above the $\mathrm{O}_{3}$ peak $(\sim 20 \mathrm{hPa})$ [Johnson et al., 2002]. We recommend PCF tables appropriate for the current standard ECC/solution pairings based on mechanical degradation and separately determine adjustments based on the effect of buffering on the 1:1 stoichiometric relationship between $\mathrm{O}_{3}$ and $\mathrm{I}_{2}$. Case in point, Watukosek, which is the only station that uses an unbuffered solution for its entire record, shows the best agreement with satellites after reprocessing when paired with the Johnson et al. [2002] PCF. Likewise, the Hanoi time series that used the unbuffered solution also show the best agreement with satellites. Complications arising from the effects of a buffered solution are removed in this case. Sondes that use unbuffered solutions do not have these secondary reactions and give good results in the stratosphere when using the appropriate Johnson et al. [2002] PCF.

Radiosonde pressure biases may also be a contributor to the variable agreement with MLS among sites at low pressure. All sites, except Ascension and Natal, have used the Vaisala RS80 radiosondes (refer to Table 3 for the time period of use at each site) for which pressure measurements are uncertain at low pressures and their biases can be either positive or negative depending on each sensor or batch of sensors in the production stream [Inai et al., 2015].

At Watukosek there is a significant increase in the correlations after reprocessing associated with a reduction in outliers (Figure $7 \mathrm{~d}$, left, red crosses). The MLS low bias relative to reprocessed $\mathrm{O}_{3}$ profiles above $12 \mathrm{hPa}$ is due to an overall increase in reprocessed $\mathrm{O}_{3}$ that shifts the original mean profile differences with MLS (Figure 7d, right). Hanoi in Figure $7 \mathrm{~g}$ (blue line) shows a similar shape and improved correlation to Watukosek, due to the influence in the response of the sensor to the $2.0 \%$ unbuffered solution.

Kuala Lumpur and Hanoi results shown in Figures 7e and $7 \mathrm{~g}$ (in red), respectively, show that the MLS and ENSCI 0.5 reprocessed sondes are more closely aligned throughout the profile. This reduction in the variability can be seen in left panels where the reprocessed sondes (red crosses) shift the MLS agreement toward the zero line compared to the original profile comparisons (black crosses).

Although the MLS is generally biased low compared to original sonde records at La Réunion, this bias is further exacerbated after reprocessing (Figure 7f, right, red profile). However, the correlations do not change significantly at all pressure levels and are well within the MLS $1 \sigma$ standard deviations (refer to Table S1 in the supporting information).

Although the pattern of agreement between sondes and MLS changes with height, it is consistent with results in Figure 4 that show an overall increase in lower stratospheric reprocessed $\mathrm{O}_{3}$. This leads to an overall improvement in the sonde/MLS agreement at Ascension, Natal, Kuala Lumpur, Hanoi, and Watukosek in the ozone maxima region (50 hPa-10 hPa), and an increase in the MLS low bias at Irene and La Réunion. 


\section{Summary}

The $\mathrm{O}_{3}$ profile data from seven sites in the SHADOZ network over the period 1998-2015 have been reprocessed to improve the quality and to establish homogeneity across the network based on ASOPOS reprocessing guidelines. We have given a detailed description of those aspects of the guidelines that correct all known biases in the ozonesonde system. Each site in the SHADOZ network is unique in its operating and reporting procedures, requiring a tailored approach based on available original data, completeness of metadata reporting, and historic knowledge (e.g., to note changes in operator procedures, personnel, degradation of equipment). To evaluate the impact of reprocessing, original and reprocessed sonde records are compared to one another and to satellite total ozone from EP-TOMS and OMI, and profiles from Aura MLS (2004-2015).

Reprocessing leads to negligible-to-modest changes in tropospheric and stratospheric column $\mathrm{O}_{3}$ : up to $8 \%$ and $6 \%$, respectively. Reprocessed data at Watukosek, Irene, and Hanoi show the largest stratospheric column $\mathrm{O}_{3}$ increases of $7.7 \pm 1.5 \mathrm{DU}, 4.0 \pm 1.7 \mathrm{DU}$, and $4.8 \pm 2.1 \mathrm{DU}$, respectively. Changes in the tropospheric $\mathrm{O}_{3}$ distribution range from $-2.1 \pm 1.3 \mathrm{DU}$ at La Réunion to $+1.2 \pm 0.7 \mathrm{DU}$ at Irene. The data from Watukosek show the largest change in $\mathrm{O}_{3}$ after reprocessing of $9.0 \pm 2.1 \mathrm{DU}$ in TCO, while Ascension and Natal show the smallest changes, up to 3 DU. There is a bimodal distribution in total, tropospheric, and stratospheric $\mathrm{O}_{3}$ at Ascension, Natal, and La Réunion due to the application of transfer functions that compensate for changes that differ from the standard ENSCI0.5 and SPC1.0 instrument and solution pairings. There is also a double peak in the distribution observed at Hanoi due to the different reprocessing procedures applied to the $\mathrm{ENSCl} 2.0$ and the ENSCI0.5 pairs.

In most cases there is a reduction in variability, i.e., $1 \sigma$ standard deviations, that leads to better overall agreement with the three satellite overpass measurements. In general, correlations and $1 \sigma$ standard deviations with EP-TOMS and OMI do not change significantly. Comparisons with MLS profiles show improved agreement in the ozone maxima region between $50 \mathrm{hPa}$ and $10 \mathrm{hPa}$. The complex response in sondes at very low pressures, when compared to MLS, indicates a need to improve the sonde measurement accuracy when the pump efficiency performance is low and to correct for pressure offsets that may arise due to the uncertainty in radiosonde pressure sensor measurements. Care should be taken when interpreting results at pressures less than $10 \mathrm{hPa}$. We recommend that analysis using ozonesonde TCO should not integrate $\mathrm{O}_{3}$ lower than $10 \mathrm{hPa}$.

The historic Irene and Kuala Lumpur $\mathrm{O}_{3}$ records have been reconstructed using monthly mean pump temperature profiles from sites that used Vaisala RS80 radiosondes because these data were missing in the original data records. An effort is ongoing to replace these climatologies with actual pump temperatures extracted from raw binary files (Geir Braathen, personal communication, 2017).

Remaining discontinuities in the $\mathrm{O}_{3}$ records at Ascension, Natal, La Réunion, and Kuala Lumpur are concurrent with a change in their radiosonde/ozonesonde system that, at present, the reprocessing method does not take into account. Solution changes at La Réunion further exacerbate inhomogeneities in their data records. Trend analyses using the La Réunion data records should not be done until the discontinuity arising from solution changes is resolved. A series of chamber tests intercomparing all the radiosonde/ozonesonde combinations used in SHADOZ is expected to resolve those issues (a JOSIE (Juelich Ozone Sonde Intercomparison Experiment) 2017).

The SHADOZ data reprocessing effort is ongoing. Once reprocessed data from the full set of SHADOZ stations have been assembled, station biases that were found in our earlier studies will be readdressed [Thompson et al., 2003, 2007, 2012]. The final step toward complete reprocessing is to assess the ozone uncertainty budget. The treatment of uncertainty in the SHADOZ ozonesonde data records will follow the recommendations and definitions by ASOPOS.

\section{Appendix A}

Supporting analyses. Descriptions are included for Figures A1-A3. 


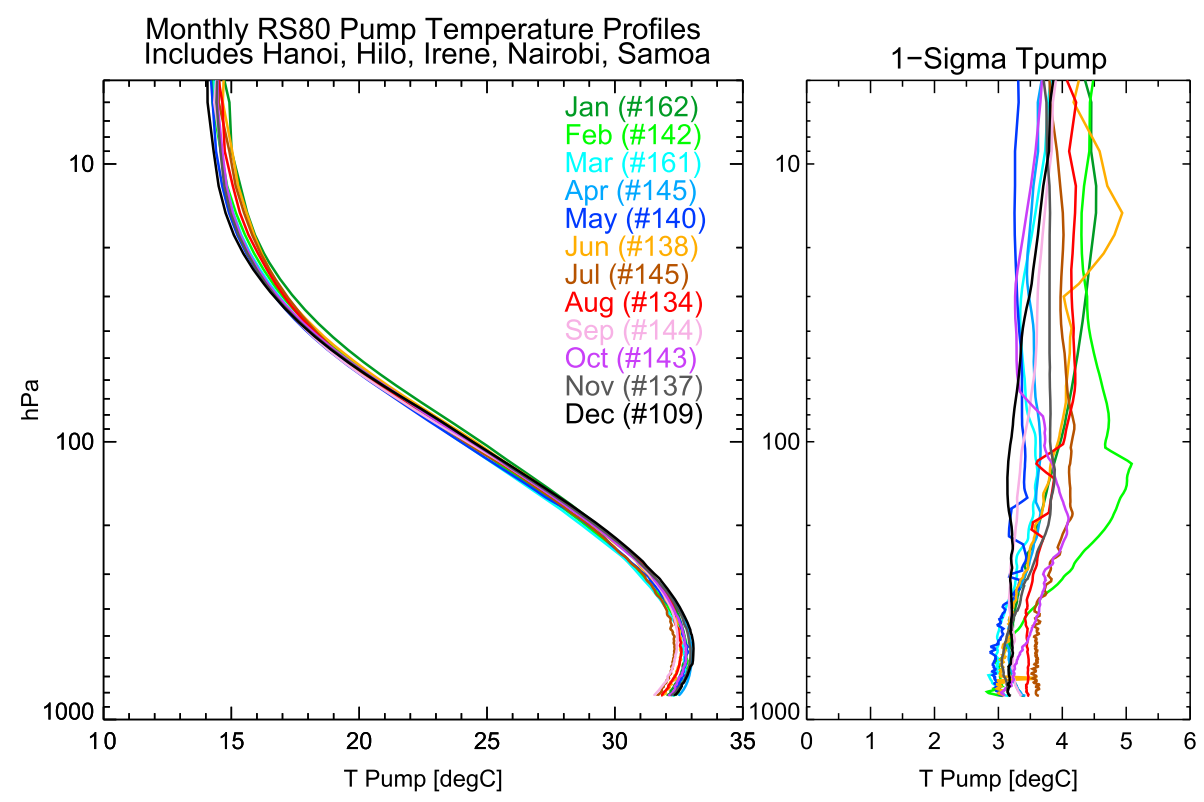

Figure A1. Monthly mean pump temperatures profiles using data from five SHADOZ sites (left) that used Vaisala RS80 radiosondes. (right) The 1 sigma standard deviation per monthly mean.
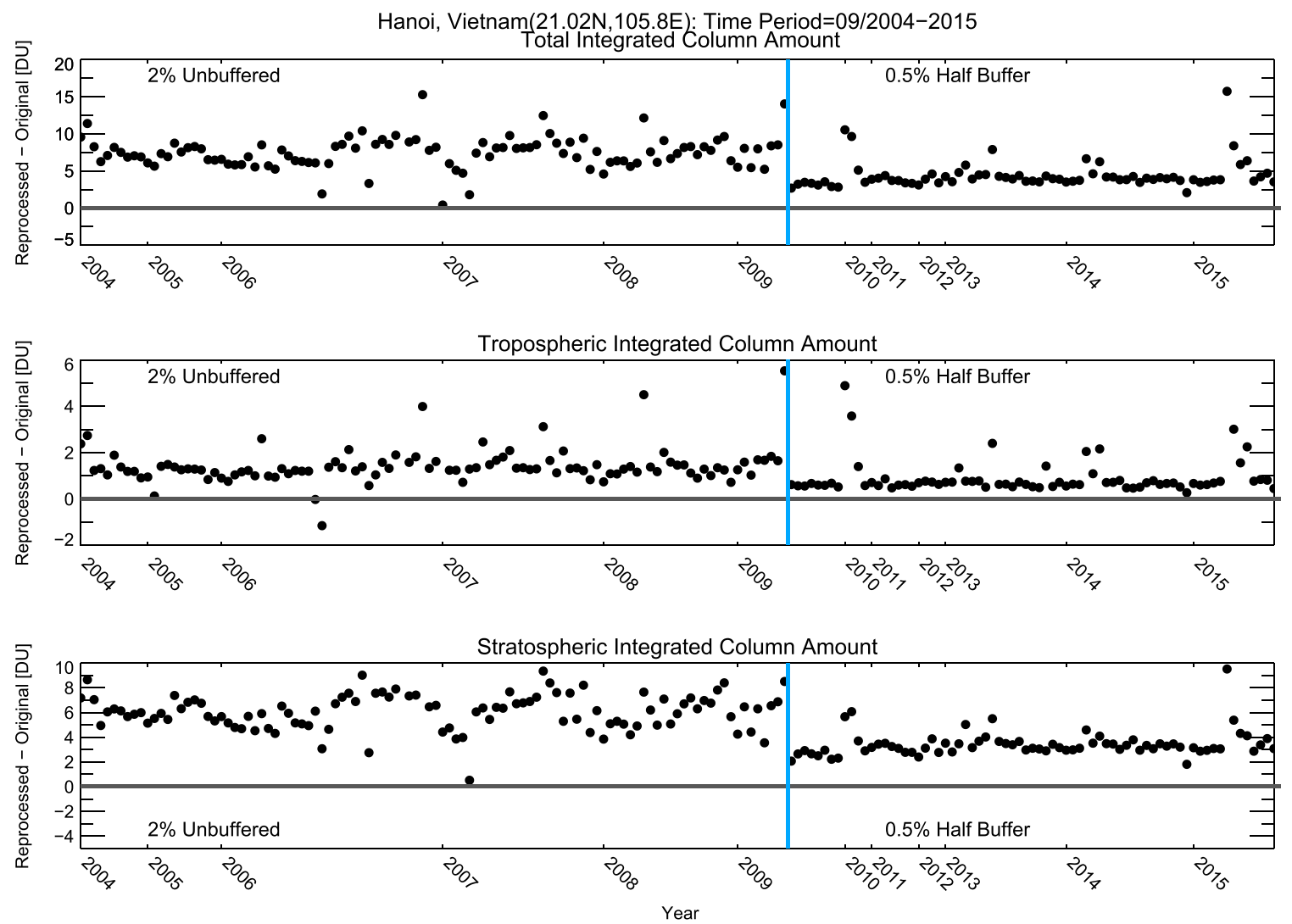

Figure A2. (top) Time series at Hanoi of ICO ${ }^{\text {total }}$, (middle) tropospheric, and (bottom) stratospheric column $\mathrm{O}_{3}$ amounts. The $y$ axis is the difference between the reprocessed and original profiles in DU. The blue line marks the boundary where $2 \%$ unbuffered and $0.5 \%$ half buffered solutions have been used. 


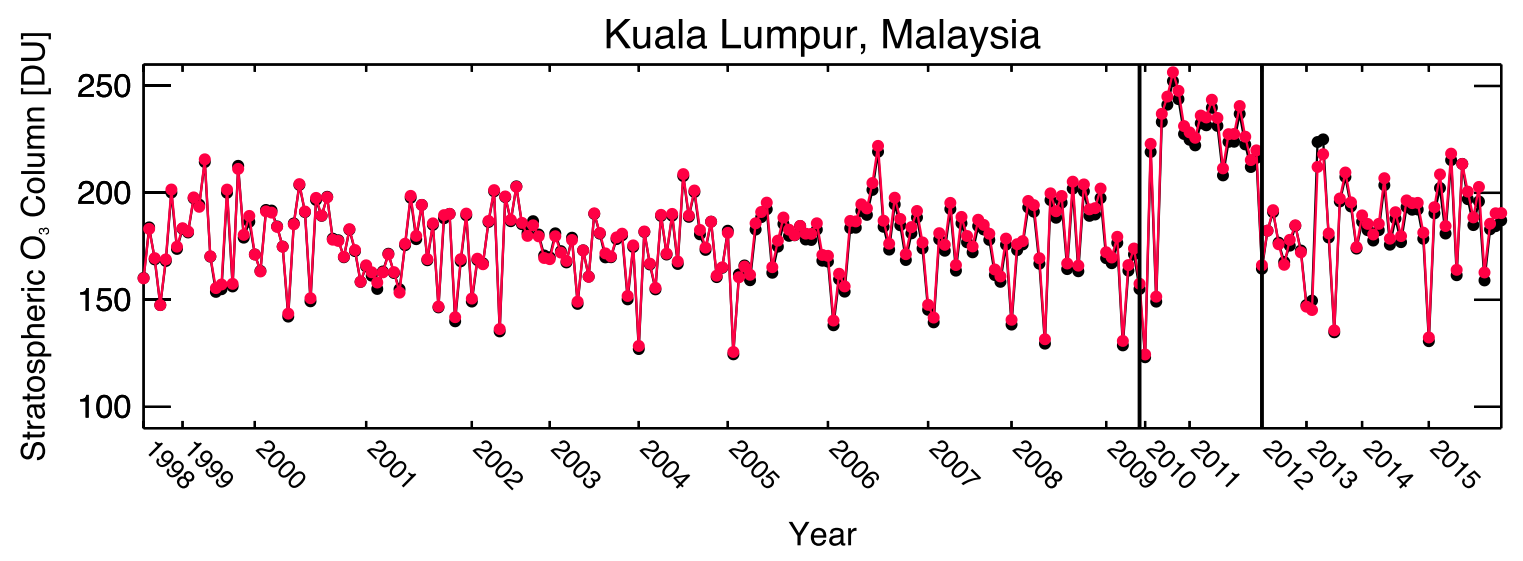

Figure A3. Time series of stratospheric column $\mathrm{O}_{3}$ at Kuala Lumpur. The time period within the black lines indicate when the Modem/ozonesonde system was flown.

\section{Acknowledgments}

Support for this study comes from NASA's Aura Validation and Upper Atmospheric Research Program (Kenneth Jucks, Manager), in partnership with NOAA/ESRL/GMD and international partners. We would like to thank the EP-TOMS Science Team, the Aura Validation Data Center (AVDC) for archiving OMI and MLS overpass data, and the SHADOZ station operators and sponsors for continued support of ozonesonde launches and contributions to this program's success. Reprocessed data shall become available in the SHADOZ archive: https://tropo.gsfc. nasa.gov/shadoz/.

\section{References}

Bandy, A. R. and A. L. Torres (1982), ECC Ozonesonde preparation and calibration procedures with ozone generating Dasibi, revision to 1977 instruction manual for Science Pump Corporation ECC-3A sensor for NASA/WFF ECC ozonesonde operations.

Birdsall, C. M., A. C. Jenkins, and E. Spadinger (1952), lodometric determination of ozone, Anal. Chem., 24(4), 662-664, doi:10.1021/ ac60064a013.

Boyd, I. S., G. E. Bodeker, B. J. Connor, D. P. J. Swart, and E. J. Brinksma (1998), An assessment of ECC ozonesondes operated using 1\% and 0.5\% Kl cathode solutions at Lauder, New Zealand, Geophys. Res. Lett., 25, 2409-2412, doi:10.1029/98GL01814.

Davies, J., C. T. McElroy, D. W. Tarasick, and D. I. Wardle (2003), Ozone capture efficiency in ECC ozonesondes; measurements made in the laboratory and during balloon flights, EAE03-A-13703, Geophysical Research Abstracts, vol. 5, 13703, EGS-AGU-EUG Joint Assembly, Nice, France, 6-11 April.

Deshler, T., et al. (2008), Atmospheric comparison of electrochemical cell ozonesondes from different manufacturers, and with different cathode solution strengths: The balloon experiment on standards for ozonesondes, J. Geophys. Res., 113, D04307, doi:10.1029/ 2007JD008975.

Deshler, T., R. Stuebi, F. J. Schmidlin, J. L. Mercer, H. G. J. Smit, B. J. Johnson, R. Kivi, R., and B. Nardi (2017), Methods to homogenize electrochemical concentration cell (ECC) ozonesonde measurements across changes in sensing solution concentration or ozonesonde manufacturer, Atmos. Meas. Tech., 10, 2021-2043, doi:10.5194/amt-10-2021-2017.

Droplet Measurement Technologies (2014), Model Z ECC ozonesondes operator manual, DOC-0336.

EN-SCI Corporation (1996), Instruction manual, model 1 Z ECC-O3 sondes, Boulder, Colo.

Hilsenrath, E., et al. (1986), Results from the balloon ozone intercomparison campaign (BOIC), J. Geophys. Res., 91(D12), 13137-13152, doi:10.1029/JD091iD12p13137.

Inai, Y., F. Hasebe, K. Shimizu, and M. Fujiwara (2009), Correction of radiosonde pressure and temperature measurements using simultaneous GPS height data, Sci. Online Lett. Atmos., 5, 109-112.

Inai, Y., M. Shiotani, M. Fujiwara, F. Hasebe, and H. Vömel (2015), Altitude misestimation caused by the Vaisala RS80 pressure bias and its impact on meteorological profiles, Atmos. Meas. Tech., 8, 4043-4054, doi:10.5194/amt-8-4043-2015.

Ivanova, G. F. (1974), Mutual dynamics of tropopause and ozonopause altitudes, Actinometry, atmospheric optics, ozonometry, 1, $170-177$.

Jiang, Y. B., et al. (2007), Validation of Aura microwave limb sounder ozone by ozonesonde and lidar measurements, J. Geophys. Res., 112, D24S34, doi:10.1029/2007JD008776.

Johnson, B. J., S. J. Oltmans, H. Vömel, H. G. J. Smit, T. Deshler, and C. Kroeger (2002), ECC ozonesonde pump efficiency measurements and tests on the sensitivity to ozone of buffered and unbuffered ECC sensor cathode solutions, J. Geophys. Res., 107(D19), 4393, doi:10.1029/ 2001JD000557.

Komhyr, W. D. (1967), Nonreactive gas sampling pump, Rev. Sci. Instrum., 38, 981-983.

Komhyr, W. D. (1969), Electrochemical concentration cells for gas analysis, Ann. Geoph., 25, 203-210.

Komhyr, W. D. and T. B. Harris (1971), Development of an ECC ozonesonde, Tech. Rep. ERL-APCL18, NOAA, Boulder, Colo.

Komhyr, W. D. (1986), Operations Handbook-Ozone Measurements to 40-km Altitude with Model 4 A Electrochemical Concentration Cell (ECC) Ozonesonde (Used With 1680 MHz Radiosondes), NOAA Tech. Memo. ERL ARL-149, pp. 1-49, Air Resources Lab., Boulder, Colo.

Komhyr, W. D., R. A. Barnes, G. B. Brothers, J. A. Lathrop, and D. P. Opperman (1995), Electrochemical concentration cell ozonesonde performance evaluation during STOIC 1989, J. Geophys. Res., 100(5), 9231-9244, doi:10.1029/94JD02175.

Komhyr, W. D. (1997), Instruction Manual - ENSCI Corporation Model KZ-ECC Atmospheric Ozone Sounding System, ENSCI Corporation, Boulder, Colo.

Levelt, P. F., G. H. J. van den Oord, M. R. Dobber, A. Malkki, H. Visser, J. de Vries, P. Stammes, J. O. V. Lundell, and H. Saari (2006), The ozone monitoring instrument, IEEE T. Geosci. Remote, 44, 1093-1101, doi:10.1109/TGRS.2006.872333.

Livesey, N. J., et al. (2016), Version 4.2x Level 2 data quality and description document, JPL D-33509 Rev. B. [Available at https://mls.jpl.nasa. gov/data/v4-2_data_quality_document.pdf.]

McPeters, R. D, et al. (1998), Earth probe Total Ozone Mapping Spectrometer (TOMS) data products user's guide, NASA Technical Publication 1998-206895, available at: http://ozoneaq.gsfc.nasa.gov/media/docs/epusrguide.pdf.

McPeters, R. D., and G. J. Labow (2012), Climatology 2011: An MLS and sonde derived ozone climatology for satellite retrieval algorithms, J. Geophys. Res., 117, D10303, doi:10.1029/2011JD017006.

McPeters, R. D., S. Frith, and G. J. Labow (2015), OMI total column ozone: Extending the long-term data record, Atmos. Meas. Tech., 8, 4845-4850, doi:10.5194/amt-8-4845-2015. 
Nash, J., R. Smout, T. Oakley, B. Pathack, and S. Kurnosenko (2005), WMO inter-comparison of high quality radiosonde systems, Vacoas, Mauritius, 02-25 February 2005, WMO/TD-No. 1303. [Available at http://www.wmo.int/pages/prog/www/IMPO/publications/IOM-83_ RSO-Mauritius/IOM-83_Radiosondes_Vacoas2005.pdf.]

Nash, J., T. Oakley, H. Vömel, and L. Wei (2011), WMO inter-comparison of high quality radiosonde systems, Yangjiang, China, 12 July - 3 August 2010, WMO/TD-No. 1580. [Available at http://www.wmo.int/pages/prog/www/IMOP/publications-IOM-series.html.]

Newton, R., G. Vaughan, H. M. A. Ricketts, L. L. Pan, A. J. Weinheimer, and C. Chemel (2016), Ozonesonde profiles from the West Pacific warm pool: Measurements and validation, Atmos. Chem. Phys., 16, 619-634, doi:10.5194/acp-16-619-2016.

Proffitt, M. H., and R. J. McLaughlin (1983), Fast response dual-beam UV-absorption photometer suitable for use on stratospheric balloons, Rev. Sci. Instrum., 54, 1719-1728.

Reid, S. J., G. Vaughan, A. R. W. Marsh, and H. G. J. Smit (1996), Accuracy of ozonesonde measurements in the troposphere, J. Atmos. Chem., 25(2), 215-226, doi:10.1007/BF00053792.

Saltzman, B. E., and N. Gilbert (1959), lodometric microdetermination of organic oxidants and ozone, resolution of mixtures by kinetic colorimetry, Anal. Chem., 31, 1914-1920.

Science Pump Corporation (1999), Operator's Manual Model 6A ECC OzoneSonde, Camden.

Smit, H. G. J., and D. Kley (1998), JOSIE: The 1996 WMO international intercomparison of ozonesondes under quasi flight conditions in the environmental simulation chamber at Jülich, WMO Global Atmosphere Watch report series, No. 130 (Technical Document No. 926). World Meteorological Organization, Geneva, Switzerland.

Smit, H. G. J., and W. Straeter (2004a), JOSIE-1998 performance of ECC ozone sondes of SPC-6A and ENSCI-Z type, WMO Global Atmosphere Watch report series, No. 157 (Technical Document No. 1218), World Meteorological Organization, Geneva, Switzerland.

Smit, H. G. J., and W. Straeter (2004b), JOSIE-2000 Jülich ozone sonde intercomparison experiment 2000: The 2000 WMO international intercomparison of operating procedures for ECC-ozone sondes at the environmental simulation facility at Jülich, WMO Global Atmosphere Watch report series, No. 158 (Technical Document No. 1225), World Meteorological Organization, Geneva, Switzerland.

Smit, H. G. J., et al. (2007), Assessment of the performance of ECC-ozonesondes under quasi-flight conditions in the environmental simulation chamber: Insights from the Jülich Ozone Sonde Intercomparison Experiment (JOSIE), J. Geophys. Res., 112, D19306, doi:10.1029/2006JD007308.

Smit, H. G. J., and the Panel for the Assessment of Standard Operating Procedures for Ozonesondes (ASOPOS) (2012), Guidelines for homogenization of ozonesonde data, SI2N/O3S-DQA activity as part of "Past changes in the vertical distribution of ozone assessment". [Available at http://www-das.uwyo.edu/\%7Edeshler/NDACC_O3Sondes/O3s_DQA/O3S-DQA-Guidelines\%20Homogenization-V219November2012.pdf.]

Smit, H. G. J., and the Panel for the Assessment of Standard Operating Procedures for Ozonesondes (ASOPOS) (2014), Quality assurance and quality control for ozonesonde measurements in GAW, World Meteorological Organization, GAW Report 201. [Available at http://www. wmo.int/pages/prog/arep/gaw/documents/FINAL_GAW_201_Oct_2014.pdf.]

Stauffer, R. M., G. A. Morris, A. M. Thompson, E. Joseph, G. J. R. Coetzee, and N. R. Nalli (2014), Propagation of radiosonde pressure sensor errors to ozonesonde measurements, Atmos. Meas. Tech., 7, 65-79, doi:10.5194/amt-7-65-2014.

Steinbrecht, W., H. Claude, F. Schönenborn, U. Leiterer, H. Dier, and E. Lanzinger (2008), Pressure and temperature differences between Vaisala RS80 and RS92 radiosonde systems, J. Atmos. Oceanic Tech., 25, 909, doi:10.1175/2007JTECHA999.1.

Tarasick, D. W., J. Davies, H. G. J. Smit, and S. J. Oltmans (2016), A re-evaluated Canadian ozonesonde record: Measurements of the vertical distribution of ozone over Canada from 1966 to 2013, Atmos. Meas. Tech., 9, 195-214, doi:10.5194/amt-9-195-2016.

Torres, A. L. (1981), ECC ozonesonde performance at high altitudes: Pump efficiency, May 1981, NASA Wallops Flight Center, NASA Technical Memorandum 73290.

Thompson, A. M., et al. (2001), Southern Hemisphere Additional Ozonesondes (SHADOZ) 1998-2000 tropical ozone climatology 1. Comparison with Total Ozone Mapping Spectrometer (TOMS) and ground-based measurements, J. Geophys. Res., 108(D2), 8238, doi:10.1029/2001JD000967.

Thompson, A. M., et al. (2003), Southern Hemisphere Additional Ozonesondes (SHADOZ) 1998-2000 tropical ozone climatology 1. Comparison with Total Ozone Mapping Spectrometer (TOMS) and ground-based measurements, J. Geophys. Res., 108(D2), 8238, doi:10.1029/2001JD000967.

Thompson, A. M., J. C. Witte, H. G. J. Smit, S. J. Oltmans, B. J. Johnson, V. W. J. H. Kirchhoff, and F. J. Schmidlin (2007), Southern Hemisphere Additional Ozonesondes (SHADOZ) 1998-2004 tropical ozone climatology: 3. Instrumentation, station-to-station variability, and evaluation with simulated flight profiles, J. Geophys. Res., 112, D03304, doi:10.1029/2005JD007042.

Thompson, A. M., et al. (2012), Southern Hemisphere Additional Ozonesondes (SHADOZ) ozone climatology (2005-2009): Tropospheric and tropical tropopause layer (TTL) profiles with comparisons to OMI-based ozone products, J. Geophys. Res., 117, D23301, doi:10.1029/ 2011JD016911.

Thompson, A. M., N. V. Balashov, J. C. Witte, J. G. R. Coetzee, V. Thouret, and F. Posny (2014), Tropospheric ozone increases over the southern Africa region: Bellwether for rapid growth in Southern Hemisphere pollution?, Atmos. Chem. Phys., 14, 9855-9869, doi:10.5194/acp-149855-2014.

Vetter, K. J. (1967), Electrochemical kinetics-theoretical and experimental aspects, translated by Academic Press Inc, 1967. Originally published as "Electrochemische Kinetik" published by Springer, Berlin-Gottengen-Heidelberg.

Vömel, H., and K. Diaz (2010), Ozone sonde cell current measurements and implications for observations of near-zero ozone concentrations in the tropical upper troposphere, Atmos. Meas. Tech., 3(2), 495-505, doi:10.5194/amt-3-495-2010.

World Meteorological Organization (WMO) (2011), Scientific Assessment of Ozone Depletion: 2010, rep. 52, chap. 2, pp. 10-17, Global Ozone Res. and Monit. Proj., Geneva, Switzerland.

Waters, J. W., et al. (2006), The Earth Observing System Microwave Limb Sounder (EOS MLS) on the Aura satellite, IEEE T. Geosci. Remote, 44, 1075-1092, doi:10.1109/TGRS.2006.873771. 